\title{
WIND PRESSURE ON A MODEL OF THE EMPIRE STATE BUILDING
}

\author{
By Hugh L. Dryden and George C. Hill
}

\section{ABSTRACT}

Measurements have been made of the distribution of wind pressure over a model of the Empire State Building for the purpose of comparing the results of model tests with measurements on the actual building now in progress under the direction of the Research Committee of the American Institute of Steel Construction. This paper describes the results of measurements on the model.

The pressure was measured at 102 stations on the model, 30 of which represent stations in the actual building, at 11 wind directions. In addition, the overturning moments were measured for the same wind directions. The results show that the pressure varies from point to point, and that reduced pressure is found over the larger part of the model. The greatest loads on the building occur when the wind blows directly against one face. A suitable value of the pressure for use in the design of tall buildings is $0.0038 V^{2}$ (in lbs./ft..2) where $V$ is the wind speed in miles per hour against which provision is to be made.

It was found that the speed of the air rushing by close to the building is greater than that of the approaching wind. Hence, an instrument mounted 15 feet above the top of the building reads too high by a factor 1.23 .

An outline is given of a method of procedure for the comparison of the results on the model with those on the actual building.

\section{CONTENTS}

I. Introduction

II. Measurements of pressure distribution

1. Apparatus ...

2. General procedure

3. Reduction of observations

4. Results

5. Discussion

III. Measurements of overturning moment

1. Apparatus and method

2. Results

3. Discussion

IV. Remarks on the method of comparing model results with full-scale measurements

V. Conclusion

\section{INTRODUCTION}

In the design of tall buildings or other structures, the pressure exerted by high winds plays an important rôle. If the structure is designed for a very large wind pressure, the cost is unnecessarily increased, a matter of concern to the owners of the structure. If the design is made for too small a wind pressure, the structure is unsafe, a matter of concern to those living or working in the building and to the general public.

The forecasting of the wind pressure to which a building may be subjected is difficult. It is practically certain that the speed of the wind will exceed 5 miles per hour at some time during nearly every day of the year. In Washington, D. C., the speed exceeds 40 miles per hour about four times a year, and has not reached 100 miles per hour in the 60 years for which records are available. It is a practical 
impossibility to design all buildings to withstand the maximum speeds which have ever been experienced anywhere. The line must be drawn at some speed which is not likely to be exceeded in the life of the building.

To obtain information on wind pressure from observations on a building in a natural wind would require years of measurement and a statistical study of the results. The data obtained from such an investigation would not be applicable to buildings of a different shape or to building's with a different exposure; for example, located in another part of the country. Some better procedure must be adopted.

The only long-continued observations on the wind are those made by the Weather Bureau. These observations give the speed and direction of the wind for different parts of the country. From these observations, the probability that a given speed will be exceeded say once in a hundred years may be computed. ${ }^{1}$ To obtain the pressure on the building, the relation between the pressure and the speed must be known. Two methods are available for determining this relation: (1) By experiments on models in wind tunnels, and (2) by observations in natural winds.

Experiments on models have been found invaluable in hydraulics and aeronautics and are well known to engineers working in those fields. Studies of wind pressure have been made by this method in this country and abroad, ${ }^{2}$ but full confidence has not been placed in the results, because of some feeling of uncertainty as to the application to buildings in a natural wind. It seemed to us that the next important step in the study of wind pressure was a coordinated program of model and full-scale experiments as applied to some existing structure.

Both methods of experiment have advantages and disadvantages. In wind-tunnel experiments, the speed and direction of the wind are under continuous control. Standard reference speeds and pressures are easily obtainable and the total force on the model may be measured

1 The Weather Bureau observations give usually only the mean speed, which is exceeded in gusts. For a discussion of this aspect of the subject see S. P. Wing, Proc. Am. Soc. Civ. Eng. 58 p. 1103, 1932 . See also R. H. Sherlock and M. B. Stout, Bull. Nat. Elec. Light Assoc., January, 1931, and January, 1932.

2 The following papers illustrate the variety of publications in this field:

A. Betz (Winddruck) Messungen von Brückenträgern. Ergebnisse der Aerodynamischen Versuchsanstalt zu Göttingen, vol. 3, p. 146, 1927.

British Elect. and Allied Industries Research Assoc. Investigations of Wind Pressure on Poles and Cables for Overhead Transmission Lines, 1925. Interim Report upon Research on Wind Pressure on Latticed Towers, 1928.

H. L. Dryden and G. C. Hill, Wind Pressures on Structures, B. S. Sci. Paper S. 523, Bull. 20, p. 697.

H. L. Dryden and G. C. Hill, Wind Pressure on Circular Cylinders and Chimneys, B. S. Jour. Research, vol. 5 (RP221), 1930.

H. L. Dryden and G. C. Fill, Wind Pressure on a Model of a Mill Building, B. S. Jour. Research, vol. 6 (R P301), 1931.

O. Flachsbart. Winddruck auf geschiossene und oflene Gebäude. p. 128. Winddruck auf Gasbehälter p. 134. Ergebnisse der Aerodynamischen Versuchsanstalt zu Göttingen, vol. 4. (R. Oldenbourg, Berlin) 1932.

O. Flachsbart. Winddruck auf Bauwerke. Die Naturwissenschaften, vol. 18, p. 475; 1930.

O. Flachsbart. Der gegenwärtige Stand der Winddruckforschung, Jahrbuch, 1930, d. Deutschen Gesell. f. Bauingenieurwesen, vol. 6, p. 108, 1931.

O. Flachsbart. Grundsätzliches zur Frage des Winddrucks auf Gebäude. Bauwelt., pp. 660 and 692, 1932.

J. O. Irminger and C. N $\emptyset$ kkentved. Wind Pressure on Buildings. Ingeniørvidenskobelige Skrifter, A Nr. 23, Kфbenhavn, 1930.

F. Nagel (Winddruck) Messungen von Profilträgern. Ergebnisse der Aerodynamischen Versuchsanstalt zu Göttingen, vol. 3, p. 151, 1927.

C. Nфkkentved. Wind Pressure on Buildings. Int. Assoc. for Bridge and Structural Engineering, Zürich, 1932.

R. L. A. Schoemaker and I. Wouters. Windbelasting op Bouwwerken, Het. Bouwbedrijf, Oct. 21, 1932 .

R. Seiferth. Winddruckmessungen an einem Gasbehalter. Ergebnisse der Aerodynamischen Versuchsanstalt zur Göttingen, vol. 3, p. 144. 1927

H. M. Sylvester. An Investigation of Pressures and Vacua Produced on Structures by Wind. Rensselaer Poly. Inst. Eng. and Sei. Series No. 31, 1931. 
as well as the detailed distribution of the pressure. The chief disadvantages are (1) that the fine detail of the actual building can not be reproduced on the model and (2) that the pressure on the fullscale building may be somewhat different than that at the corresponding location on the model because of the existence of a scale effect. It is our belief that the errors due to failure to reproduce the fine detail and due to scale effect are not very large, but until this belief is actually confirmed by full-scale experiments, results from model tests will not command the full confidence of engineers engaged in the design of buildings.

In experiments in natural winds, the conditions are reversed. It is no longer easy to obtain conditions favorable for measurement, in that the speed and direction of the wind change continuously. In addition, it is very difficult to obtain a steady reference pressure, or otherwise expressed, to measure the "normal" atmospheric pressure. On the other hand, there is no question of scale effect or of lack of detail of a model.

When it was announced by the American Institute of Steel Construction that a program of wind-pressure measurements would be conducted on the Empire State Building, the Bureau of Standards saw an opportunity to test the utility and validity of model measurements. Through the cooperation of the engineer, H. G. Balcom, drawings of the building were generously supplied. A model was designed and constructed by the Bureau of Standards, and measurements of wind pressure were made in the 10 -foot wind tunnel. The results of measurements on the model are described in this paper. Measurements on the actual building are in progress under the direction of $\mathrm{F} . \mathrm{H}$. Frankland, chairman of the Research Committee of the American Institute of Steel Construction. When the results become available, comparisons can be made.

\section{MEASUREMENTS OF PRESSURE DISTRIBUTION}

\section{APPARATUS}

The Empire State Building is 1,250 feet high; the model, shown in Figure 1 , is 5 feet high. The model is made of rolled aluminum plates one-quarter inch thick, except the tower, which is constructed of wood. It represents the building in external shape except for the minor irregularities of the surface on a scale of 1 to 250 . It does not represent the actual building in material, method of construction, or strength. It is not tested to failure, but is used only for measurements of the wind pressure at different wind speeds.

The wind pressure on the actual building is to be measured on the thirty-sixth, fifty-fifth, and seventy-fifth floors by means of pipes running from the outside face of the walls to manometers mounted at suitable observing stations. At the levels on the model corresponding to these floors as shown in Figure 4, 17 pressure stations were prepared as follows: A hole approximately one-quarter inch in diameter was drilled and tapped at each station. A hollow cylindrical threaded plug about five-eighths inch long and closed at one end was screwed into the hole and the closed end carefully worked down so as to make it flush with the outer surface of the model. After polishing, a small hole approximately 0.040 inch in diameter was drilled along the axis of the plug from the outside face inward. By means of rubber tubing, 
connection could then be made through the interior of the model from each station to the pressure gauge.

Fourteen of the seventeen stations at each level were located on two adjacent faces of the model as shown by the short solid lines in Figures 2 and 3 , stations designated as $1,2,3,4,5,7,8,9,11,12,13$, 15,16 , and 17. Three were located on the other faces. Because of the symmetry of the model, the complete distribution at each wind direction could be obtained by two runs, one with the wind striking the faces containing the large number of stations, the second with the model rotated through $180^{\circ}$. The levels are denoted by the letters $A, B$, and $C$, and the stations by numbers from 1 to 34 . The short solid lines show stations actually present in the model; the dotted

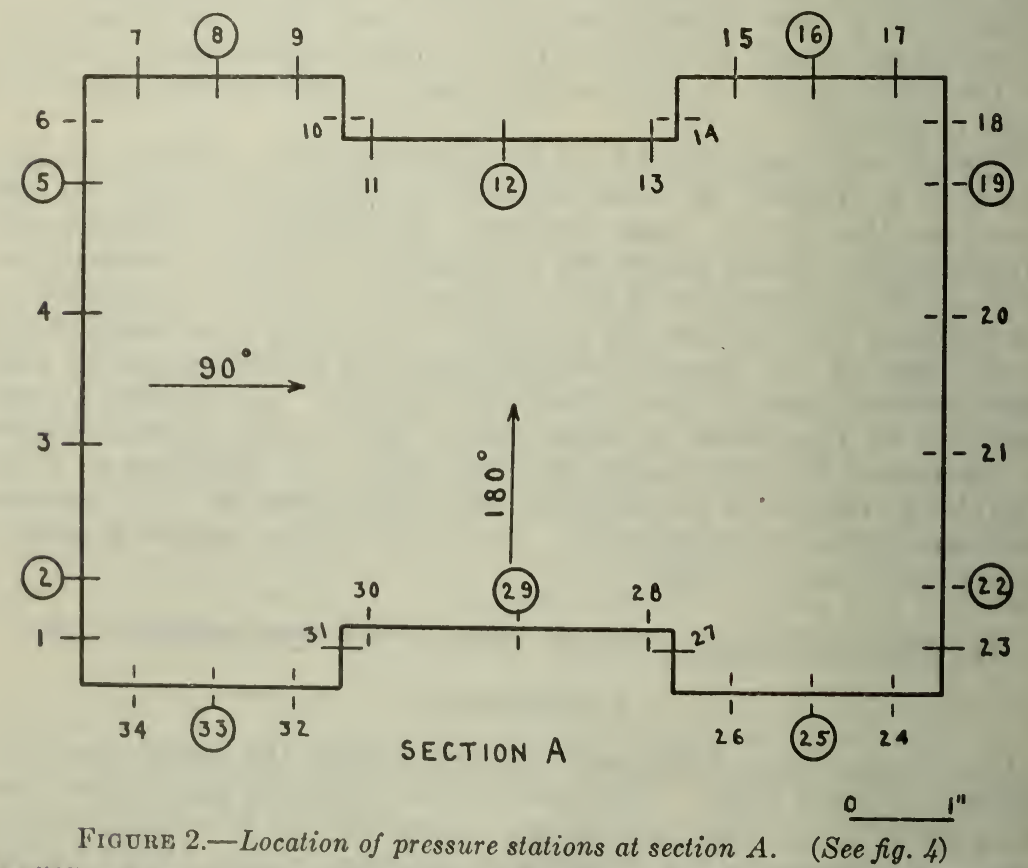

The solid lines represent stations present in the model, the dotted lines, those for which values are obtained hy rotating the model through $180^{\circ}$, the numbers inclosed in circles, those present in the actual building. The designation of wind direction is shown by the arrows.

lines represent stations for which values are obtained by rotating the model through $180^{\circ}$, while the numbers inclosed in circles correspond to stations present in the actual building.

The model rests on and is attached to a circular plate as shown in Figure 1, which also shows the mounting in the wind tunnel. The circular plate can be rotated with respect to a second square plate below, the square plate being fastened to a wooden platform. Since the tunnel is cylindrical, the platform rests on two wooden segments cut to the curvature of the tunnel wall. Both plates have an opening in the center to permit the passage of the 51 connecting tubes from the stations. The circumferential edge of the circular plate is graduated at intervals of $5^{\circ}$ and the square stationary plate has an index mark at the center of its upstream face. 


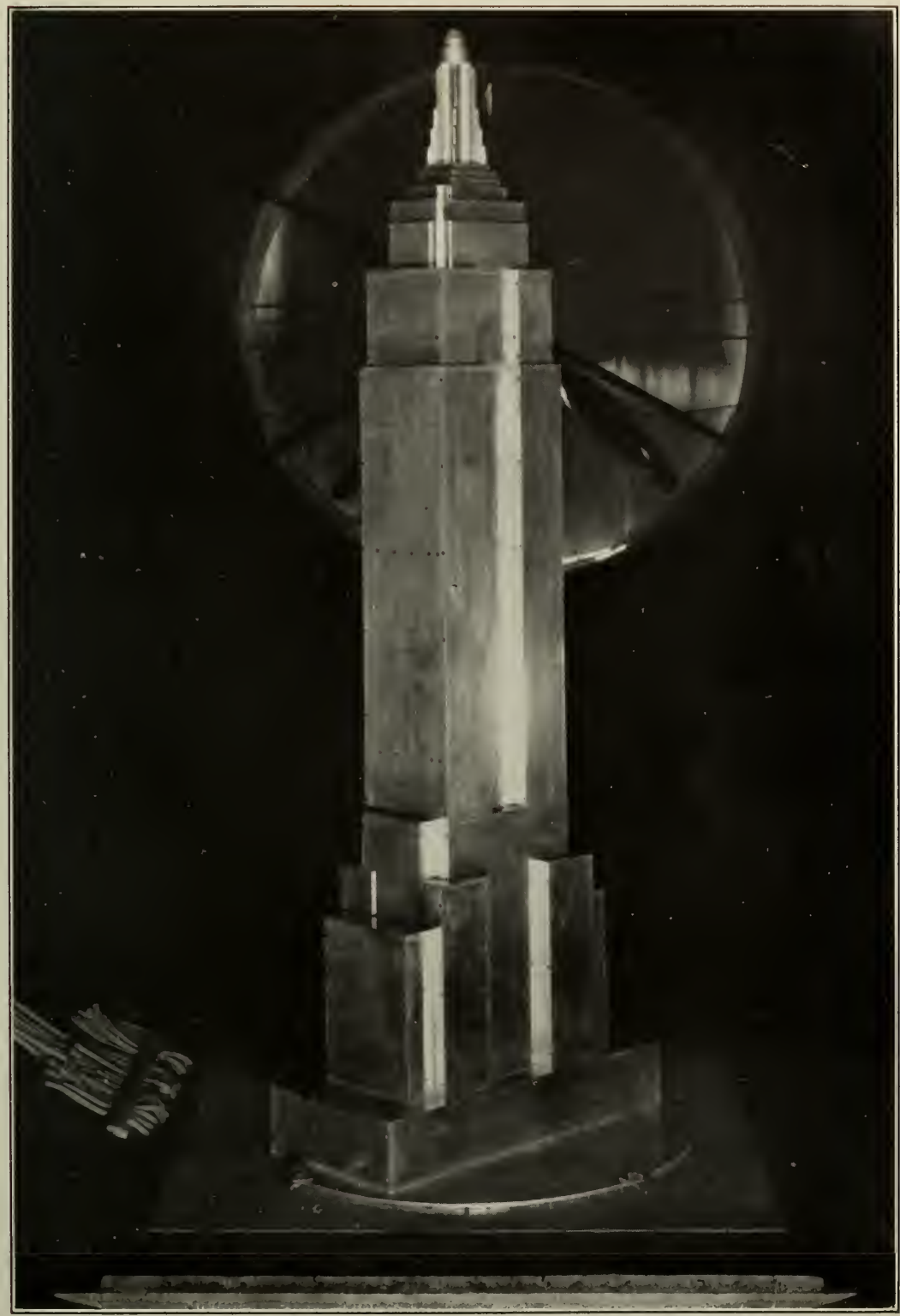

Figure 1.-Model of the Empire State Building in the wind tunnel, looking downstream

The brass screws holding the model together and the brass plugs in which the pressure holes are drilled appear as dark spots. 
The 10-foot wind tunnel which was used for these measurements has been described in Scientific Paper No. 523. That paper also gives an account of the method of measuring wind speed, and a description of the manometer used for measuring pressures. In the present tests, speeds up to about 55 miles per hour were used.

\section{GENERAL PROCEDURE}

The general procedure in making the measurements of pressure distribution was as follows: The model was first set with the narrow face containing the five pressure stations normal to the wind direction, an azimuth designated as $90^{\circ}$. Twelve stations were connected to the 12 tubes of a multiple-tube manometer, the reservior of the manometer being connected to a static plate upstream from the model. The pressure at the opening of the static plate served as the

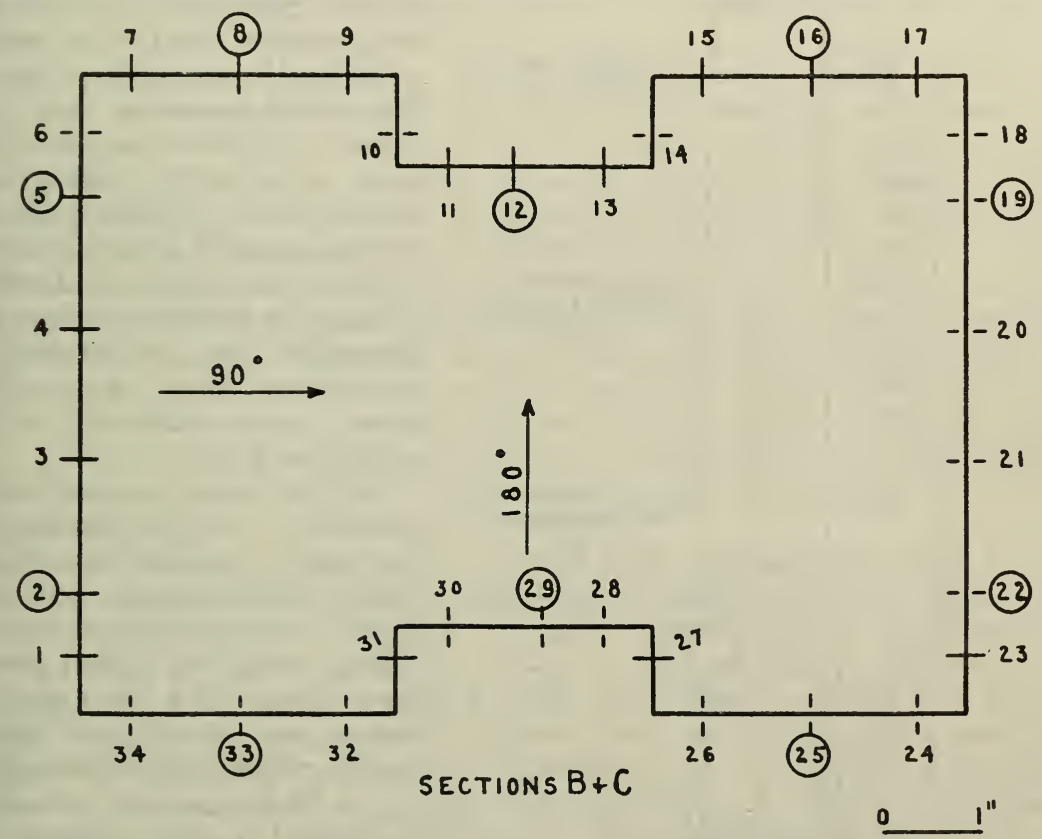

Figdre 3.-Location of pressure stations at sections B and C. (See fig. 4)

See note for Figure 2.

base pressure from which all other pressures were measured. At wind speeds of approximately 40,60, and 80 feet per second (27, 41, and 55 miles per hour), an observer read successively the 12 tubes of the manometer, which gave readings proportional to the differences in pressure between the holes at the surface of the model and the pressure at the static plate. Twelve other stations were then connected, readings taken, and the process repeated until observations were completed for the 51 stations. The model was then turned through an angle of $180^{\circ}$ and the series repeated. A complete set of observations at the 102 stations was made for wind directions from $90^{\circ}$ to $180^{\circ}$ at intervals of $10^{\circ}$ and at $135^{\circ}$. 


\section{REDUCTION OF OBSERVATIONS}

When an air stream blows against an object, the pressure, $p$, at any point on its surface may be regarded as consisting of two parts-the

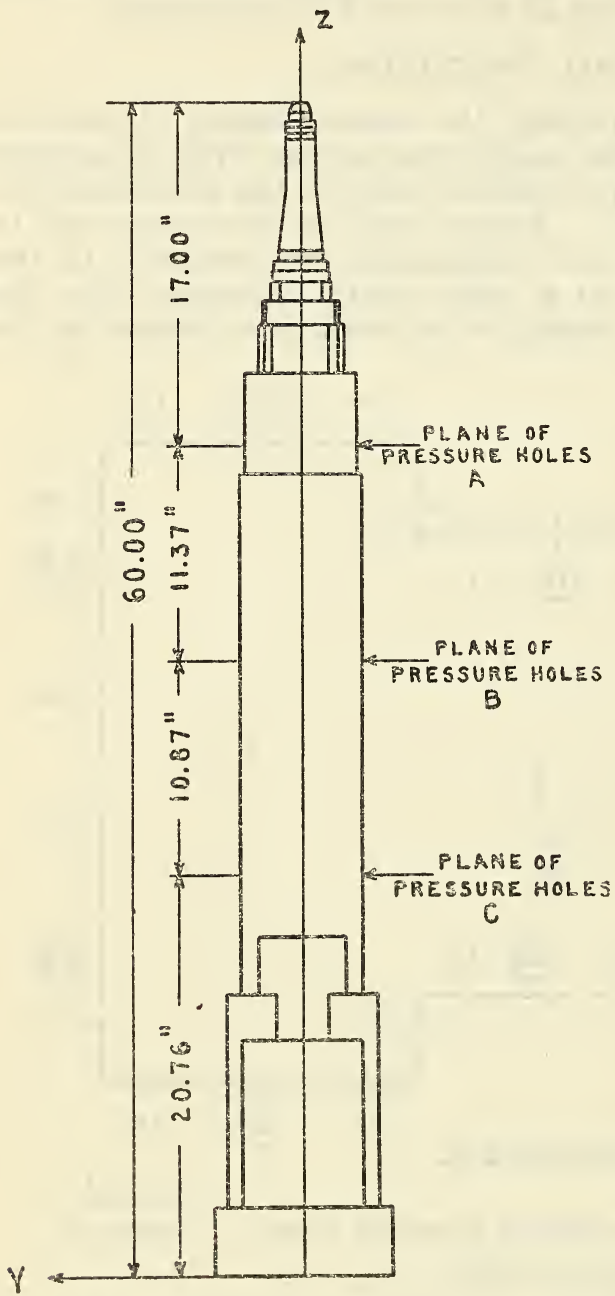

FIGURE 4.-Location of sections $A, B$, and $C$ and the axes of reference on the model

The $X$ axis runs into the plane of the paper at right angles to the $Y$ and $Z$ axes which are snown reasoning teaches that $p_{w}$ will be given by an expression of the form

$$
\frac{p_{10}}{q}=f\left(\frac{V L \rho}{\mu}\right)
$$

where $q$ is the velocity pressure $\left(1 / 2 \rho V^{2}\right), \rho$ the air density, $V$ the wind speed, $\mu$ the viscosity of the air, and $L$ a linear dimension fixing the

3 'The term static piessure is u ed to indicate the pressure which would be measured by a pressure gauge moving with the air, and, therefore, "static" with respect to the air. In actual practice the measurement is made by means of holes in the side of a closed tube, the axis of which is parallel to the wind direction. The form of the tube is such that the air flows smoothly past the holes. 
scale. The expression applies only to geometrically similar bodies. The wind pressure, $p_{w}$ could be measured in any convenient units, but there are advantages in using the velocity pressure, $q=1 / 2 \rho V^{2}$, as the unit. For bodies without curved surfaces and with sharp corners, $p_{w} / q$ is practically independent of the wind speed and the size of the model (that is, $f\left(\frac{V L \rho}{\mu}\right)$ is a constant for any station), so that from a single value of it for any given shape of body the pressure at the corresponding point on a similar body of any size at any wind speed can be readily computed with the aid of a table of velocity pressures. The ratio is a pure number independent of the units used so long as the pressures are all measured in the same units.

The engineer is in most cases more directly concerned with the resulting forces than with the pressures themselves and their distribution. These resulting forces always involve the pressure acting on the opposite sides of the surface or object. In the case of a hollow object, such as a building, which is open to the outside at various places, air currents are set up within the building, and there is a distribution of wind pressure over the interior as well as the exterior surfaces of the walls. At any point of the wall the force per unit area tending to move the wall normal to itself equals the difference between the wind pressure on the two sides and is in the direction from the higher toward the lower pressure. Little is known at the present time as to the distribution of wind pressure over the interior walls of actual buildings in high winds and in the presentation of data for the distribution over the exterior it is commonly assumed that the interior is at a constant pressure equal to the static pressure, $p_{s}$; that is, $p_{w}$ is zero for the interior. If the pressure on the interior is constant, it has no effect on the resultant force tending to overturn the building, no matter what its value.

By definition, $p_{s}$ is the same at every point of the surface and, hence, it contributes nothing to the resulting forces and may be ignored in the computations. The force on any element, $d A$, is equal to $p d A$ and acts in the direction of the normal to the surface. ${ }^{4}$ In the case of a building with plane surfaces, with all angles between the planes right angles, the component of force along each axis of the building is readily computed. The faces parallel to an axis contribute nothing to the component of the force along that axis. Each of the faces perpendicular to the axis contributes the summation of the forces on the elements, that is, $\int \mathcal{S} p d A$; but account must be taken of the fact that forces on opposite faces oppose each other. Since the net effect of $p_{s}$ vanishes, we need only compute $\int \mathcal{S} p_{v} d A$. Dividing by $q$, we have the force $F$ given by

$$
F / q=\iint p_{w} d A
$$

It is found convenient to divide this expression by the area of projection, $A_{p}$, of the body on a plane normal to the axis under consideration. The quotient $F / A_{p} q$ is called the force coefficient. ${ }^{5}$ It is the average force per unit projected area divided by the velocity pressure; that is, the ratio of the effective resultant pressure on the total projected area to the velocity pressure. The force in any particular case is obtained by multiplying the force coefficient by the projected area and by the velocity pressure.

4 Excluding frictional effects, which are of importance only in special cases.

s The terms "resistance coefficient," "drag coefficient," "shape coefficient" are also used. 
In the case of the present model we shall be interested in the average loading at a given elevation. In this case the force per unit length is equal to the summation of $p_{w} d s$; that is, $\int p_{v} d s$ where $d s$ is an element of the width of the face. Again it is convenient to divide $\int p_{w} d s$ by the width and by the velocity pressure $q$ so as to obtain a coefficient applicable to the particular section, giving the average force per unit area per unit velocity pressure.

It will be noted that in all cases, an average value of $\frac{p_{w}}{q}$ is determined, which if uniformly distributed over the area in question would give the correct value of $F / q$.

For the convenience of the reader, the relation between the indicated speeds, as measured by 3 and 4 cup U. S. Weather Bureau anemometers, and the true speed is given in Table 1 , and the velocity pressures at various true speeds for air of standard density is given in Table 2.

TABLE 1.-Indicated wind speeds by Robinson cup anemometers ${ }^{1}$

\begin{tabular}{|c|c|c|c|c|c|}
\hline True speed (miles per hour) & $\begin{array}{l}\text { Indicated } \\
\text { speed, } \\
\text { old 4-cup } \\
\text { standard }\end{array}$ & $\begin{array}{l}\text { Indicated } \\
\text { speed, } \\
\text { new 3-cup } \\
\text { standard }\end{array}$ & True speed (miles per hour) & $\begin{array}{l}\text { Indicated } \\
\text { speed, } \\
\text { old 4-cup } \\
\text { standard }\end{array}$ & $\begin{array}{l}\text { Indicated } \\
\text { speed, } \\
\text { new 3-cup } \\
\text { standard }\end{array}$ \\
\hline $\begin{array}{l}5 \\
10 \\
15 \\
20 \\
25 \\
30\end{array}$ & $\begin{array}{r}5 \\
11 \\
17 \\
23 \\
30 \\
37\end{array}$ & $\begin{array}{r}5 \\
10 \\
15 \\
20 \\
25 \\
31\end{array}$ & 60 & $\begin{array}{r}78 \\
85 \\
91 \\
98 \\
105 \\
112\end{array}$ & $\begin{array}{l}63 \\
68 \\
73 \\
79 \\
84 \\
89\end{array}$ \\
\hline 450 & $\begin{array}{l}44 \\
50 \\
57 \\
64 \\
71\end{array}$ & $\begin{array}{l}3 \dot{0} \\
41 \\
47 \\
52 \\
57\end{array}$ & 1005 & $\begin{array}{l}118 \\
125 \\
132 \\
138 \\
145\end{array}$ & $\begin{array}{r}95 \\
100 \\
105 \\
111 \\
116\end{array}$ \\
\hline
\end{tabular}

1 Before Jan. 1, 1928, the U. S. Weather Bureau used the 4-cup instrument; from then until Dec. 31, 1931, the 3 -cup instrument. After that date all wind speeds have been corrected before publication, thus giving
true speeds.

$\mathrm{T}_{\mathrm{ABLE}}$ 2.-Velocity pressures at several wind speeds

\begin{tabular}{|c|c|c|c|c|c|}
\hline $\begin{array}{l}\text { True wind speed } \\
\text { (miles per hour) }\end{array}$ & $\begin{array}{l}\text { Velocity } \\
\text { pressure }\end{array}$ & $\begin{array}{l}\text { True wind speed } \\
\text { (miles per hour) }\end{array}$ & $\begin{array}{l}\text { Velocity } \\
\text { pressure }\end{array}$ & $\begin{array}{l}\text { True wind speed } \\
\text { (miles per hour) }\end{array}$ & $\begin{array}{l}\text { Velocity } \\
\text { pressure }\end{array}$ \\
\hline $\begin{array}{l}5 \ldots \ldots \ldots \\
10 \ldots \ldots \\
150 \ldots \ldots\end{array}$ & $\begin{array}{r}\text { Lb8./ft. }{ }^{2} \\
0.064 \\
.256 \\
.575 \\
1.023\end{array}$ & $\begin{array}{l}45 \\
50 \\
55 \\
60\end{array}$ & $\begin{array}{r}\text { Lbs./ft. }{ }^{2} \\
5.179 \\
6.391 \\
7.737 \\
9.208\end{array}$ & $\begin{array}{l}85 \\
90 \\
95 \\
100\end{array}$ & $\begin{array}{r}\text { Lbs./ft. } \\
18.48 \\
20.72 \\
23.08 \\
25.58\end{array}$ \\
\hline $\begin{array}{l}25 \ldots . \\
30 . \ldots \\
350 . \\
40 \ldots\end{array}$ & $\begin{array}{l}1.600 \\
2.302 \\
3.133 \\
4.092\end{array}$ & $\begin{array}{l}65 \\
70 \\
75 \\
75 \\
80\end{array}$ & $\begin{array}{l}10.81 \\
12.53 \\
14.39 \\
16.37\end{array}$ & $\begin{array}{l}105 \\
110 \\
115 \\
120\end{array}$ & $\begin{array}{l}28.20 \\
30.95 \\
33.83 \\
36.83\end{array}$ \\
\hline
\end{tabular}

Note.-Velocity pressure in lbs./ft. ${ }^{2}=0.001189\left(V \times{ }^{23}(\mathrm{~s})^{2}\right.$ where $V$ is the true speed in miles per hour, and the density is that at $15^{\circ} \mathrm{C} ., 760 \mathrm{~mm} \mathrm{Hg}$.

In an actual structure the wind pressure is modified by the presence of the ground, so that some method must be used in the artificial wind to produce the effect of the ground. In the present experiments the model rested on the floor of the tunnel except for the interposition of a small platform to provide for the curvature of the tunnel wall. In this case the wind is not uniform over the region occupied by the model. Figure 5 shows the measured speed above the tunnel floor 
in the absence of the model along the line subsequently occupied by the vertical axis of the model. The speeds are expressed as ratios to the reference speeds given by a Pitot tube located upstream and to one side. The speeds at points within the area occupied by the model are approximately the same at a given elevation. From the curve it is seen that the wind speed above an elevation of 18 inches is approximately uniform. Since the elevation of the lowest pressure holes is 20.76 inches, all pressure stations on the model are within the region of uniform speed. When a speed of 80 feet per second is desired at the model, the reference speed must be set a little lower as indicated by the curve.

The results finally desired are $p_{w}$, the changes in pressure produced by the presence of the model. It was necessary, therefore, to measure the difference in pressure between the reference (static plate) pressure and the static pressure in the tunnel (with the model removed) at the place previously occupied by the model and to add this value with proper sign to the observed pressure.

The procedure in reducing the observations was as follows: The readings of the manometer were reduced to absolute pressure differences in pounds per square foot from a knowledge of the slope of the manometer and the density of the liquid used (kerosene).

The pressure differences were then corrected for the difference between the reference pressure and the static pressure and expressed as fractions of the velocity pressure. The values for any one station at the three speeds were, in general, very nearly the same, the variation from the mean in most cases not exceeding 0.03 .

\section{RESULTS}

The mean values of $p_{w} / q$ are given in Tables 3 to 6 , inclusive, and plotted in Figures 6 to 16, inclusive. In these figures, two horizontal sections of the model are shown, the upper for

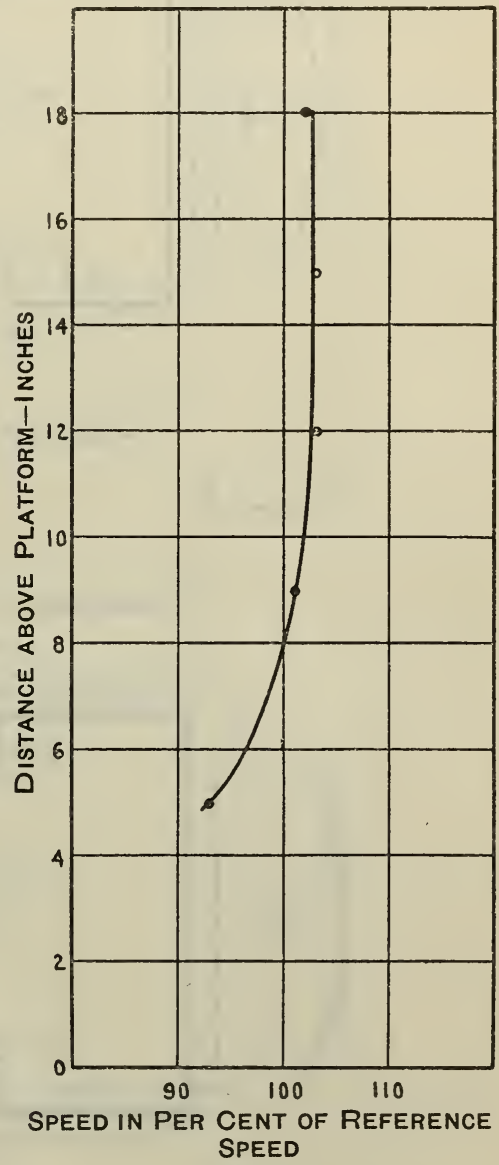

FIGURE 5.-Variation of wind speed above the platform in the absence of the model

elevation $A$, the lower for elevations $B$ and $C$. Just outside the section drawings are four fine base lines from which the values of $p_{w} / q$ are plotted to the scale shown. In the lower plot, the solid curves are for elevation $B$ and the dash curves for elevation $C$. At each elevation there are four holes in the recesses, and the values of $p_{v} / q$ for these holes are indicated by the small circles and crosses. In the lower plot, the circles are for elevation $B$, the crosses for elevation $C$. The wind direction is 
indicated by the arrow, and the number gives the angle which the wind makes with the face containing pressure stations 1 to 6 . When $p$ is larger than $p_{s}, p_{w} / q$ is positive; when $p$ is smaller than $p_{s}, p_{w} / q$ is
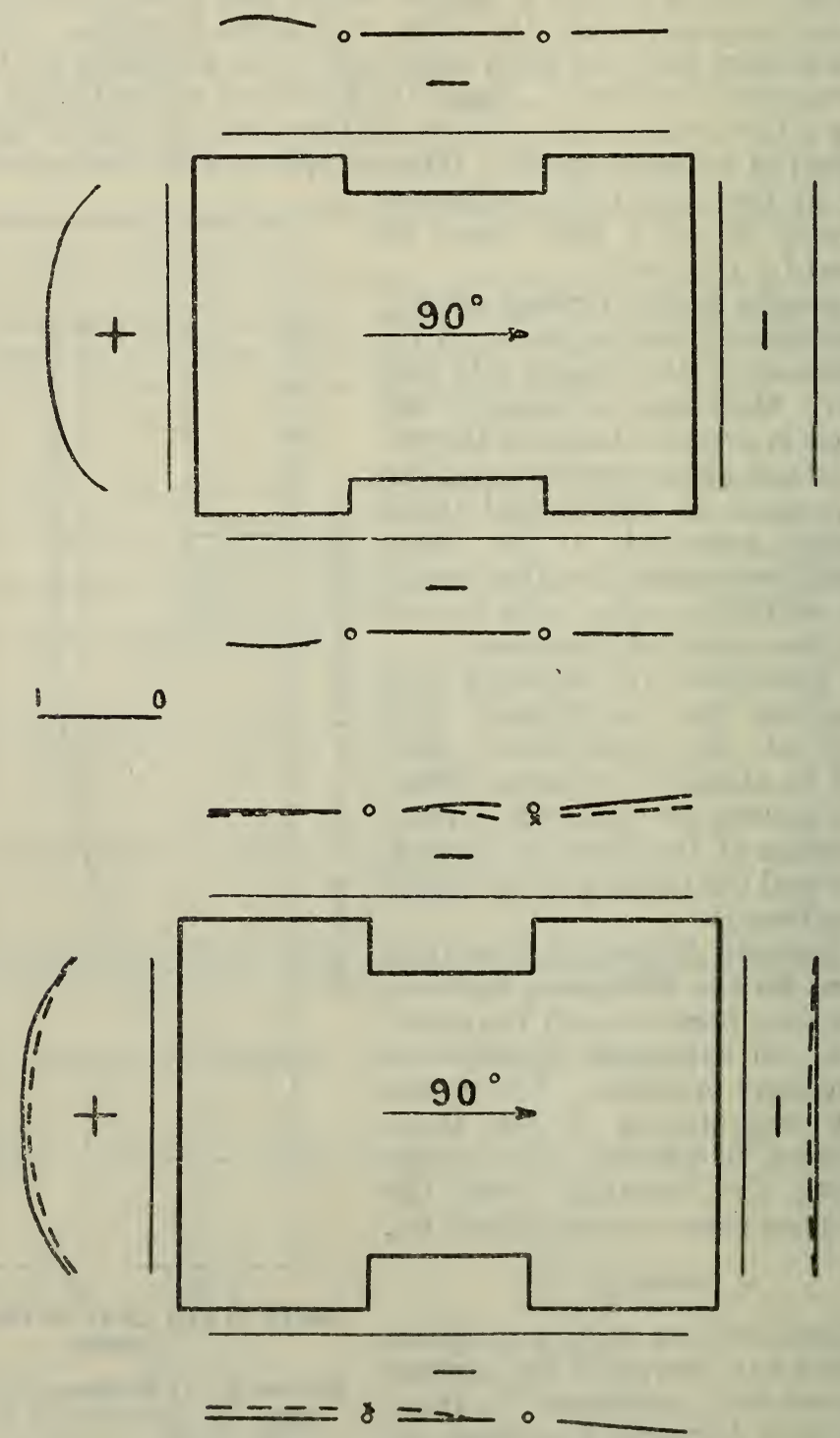

FIgURE 6.-Distribution of pressure at sections $A, B$, and $C$ at $90^{\circ}$ to the wind

Above, section $A$; below, solid lines, section $B$; dotted lines, section $C$

The pressures are measured from the static pressure as base and expressed as ratios to the velocity pressure. The ratios are plotted outward from the thin base lines to the scale shown. Minus signs denote that the pressure is lower than the static pressure. The circles and crosses give the values at stations 10, 14, 27, and 31 on the side walls of the embrasures.

negative. Both positive and negative values are plotted outward from the datum line for convenience and are distinguished by the use of plus and minus signs. 

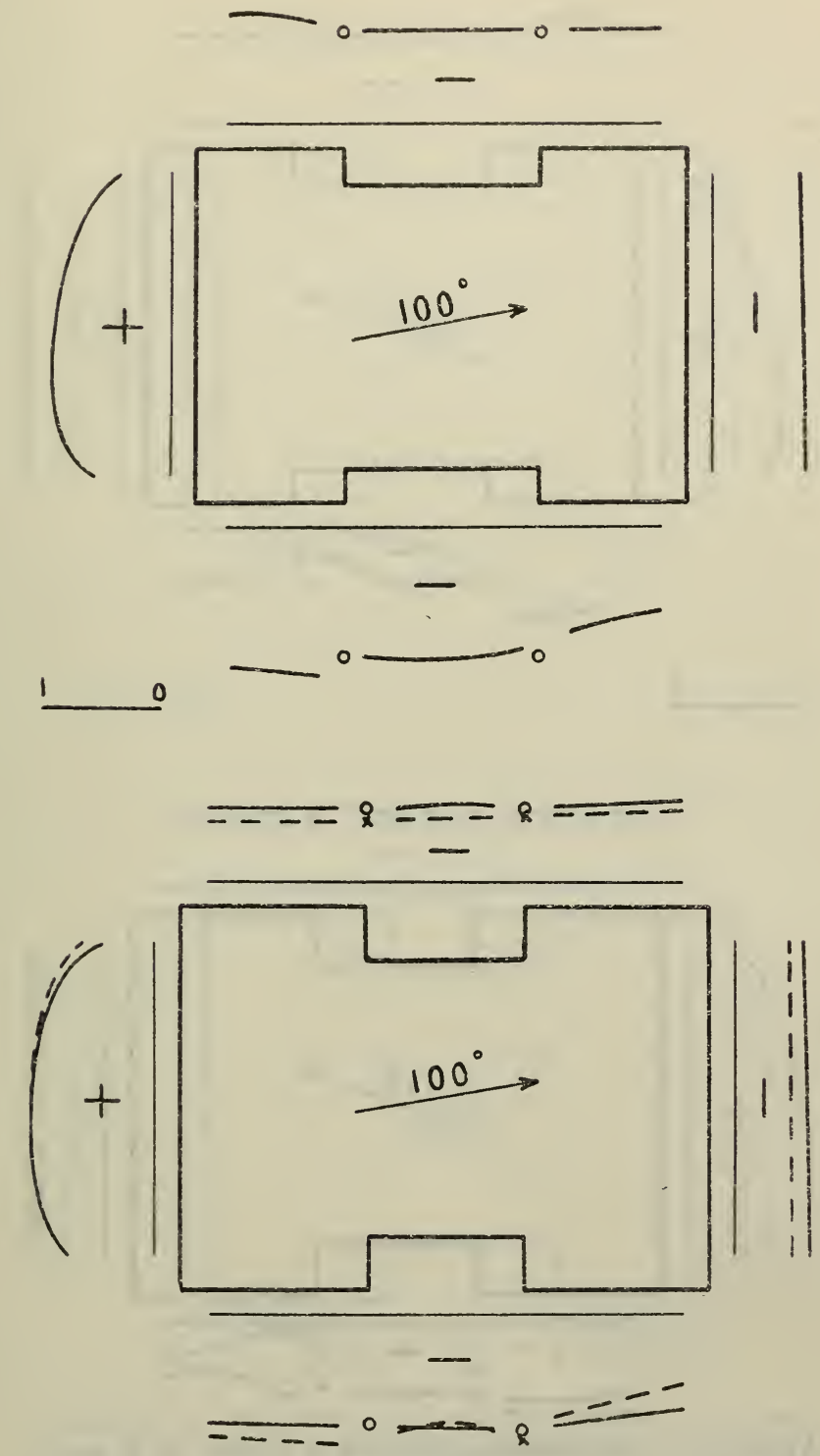

FIGURE 7.-Distribution of pressure at sections $A, B$, and $C$ at $100^{\circ}$ to the wind

See legend of Figure 6 

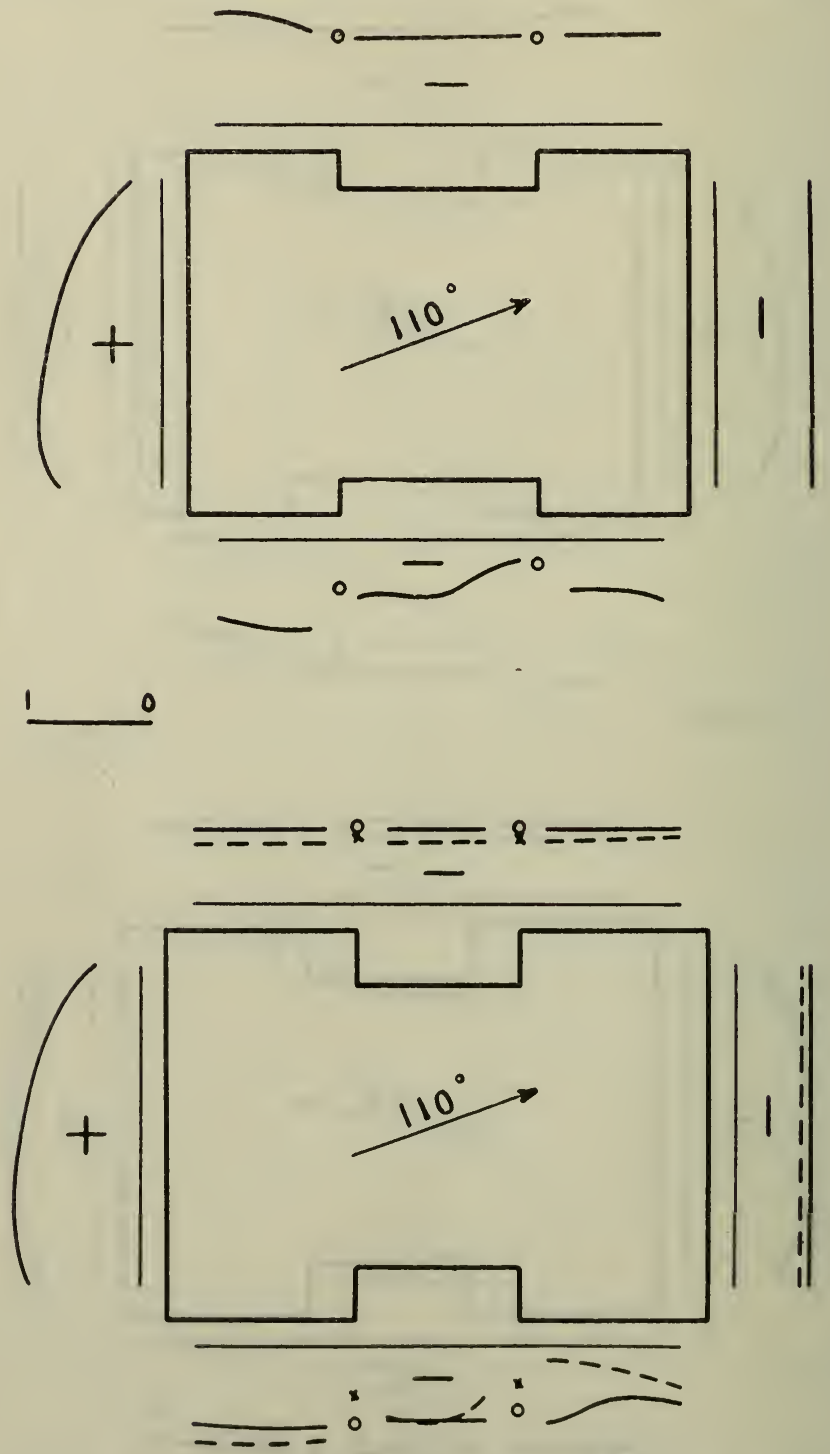

Figure 8.-Distribution of pressure at sections $A, B$, and $C$ at $110^{\circ}$ to the wind

See legend of Figure 6 

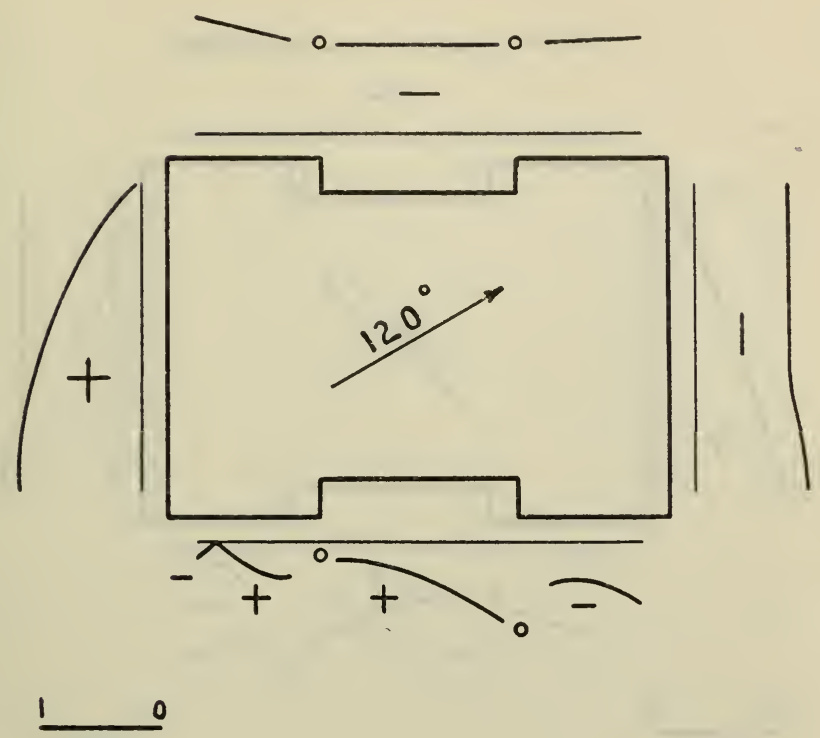

$\overline{----}: \overline{---.}: \overline{=--}$

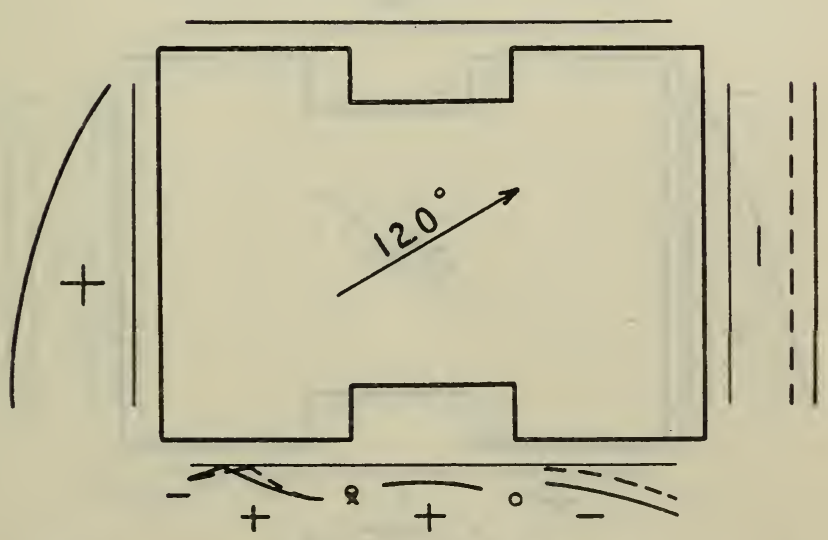

Figdre 9.-Distribution of pressure at sections $A, B$, and $C$ at $120^{\circ}$ to the wind 

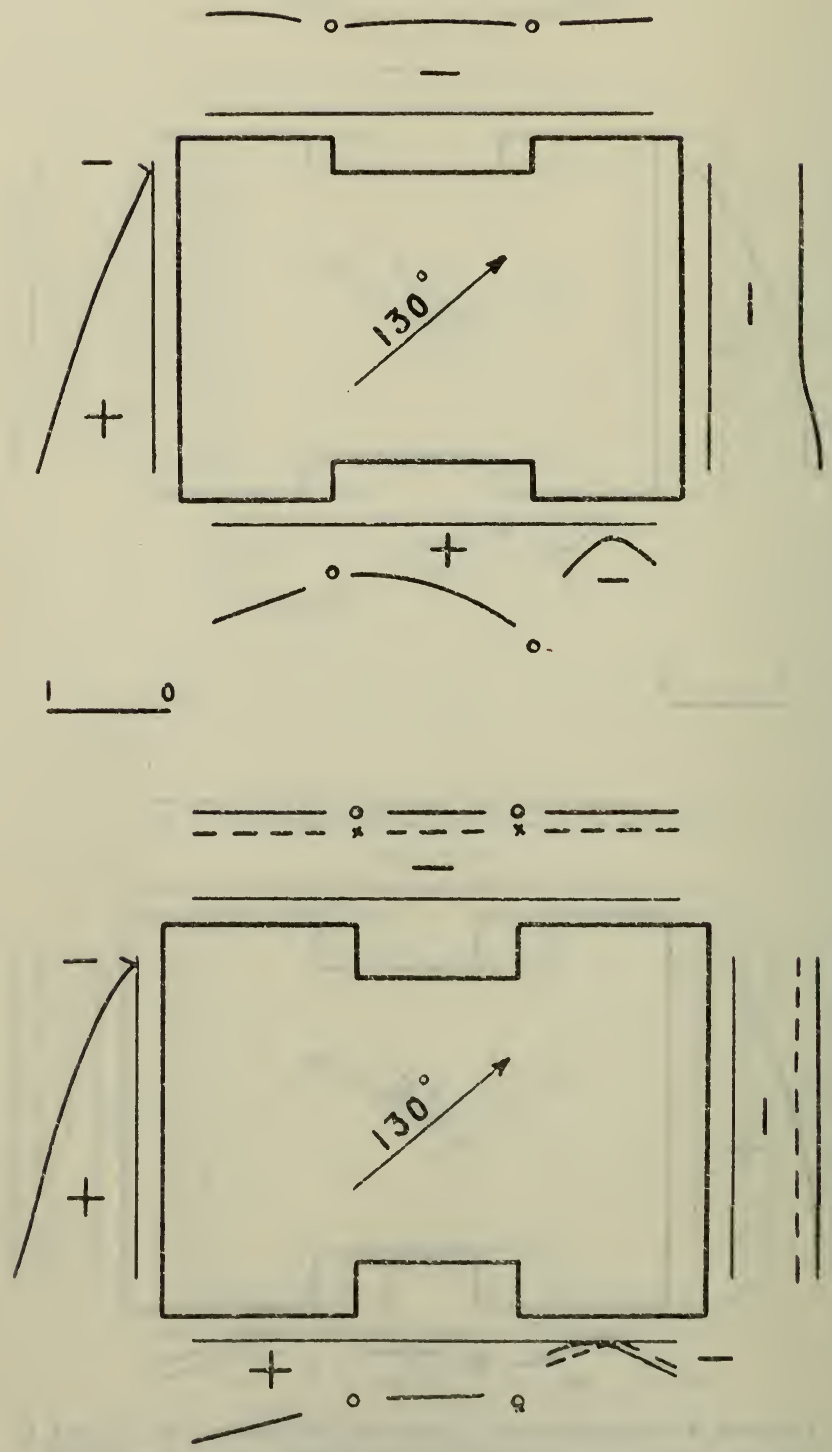

Figure 10.-Distribution of pressure at sections $A, B$, and $C$ at $130^{\circ}$ to the wind

See legend of Figure 6 

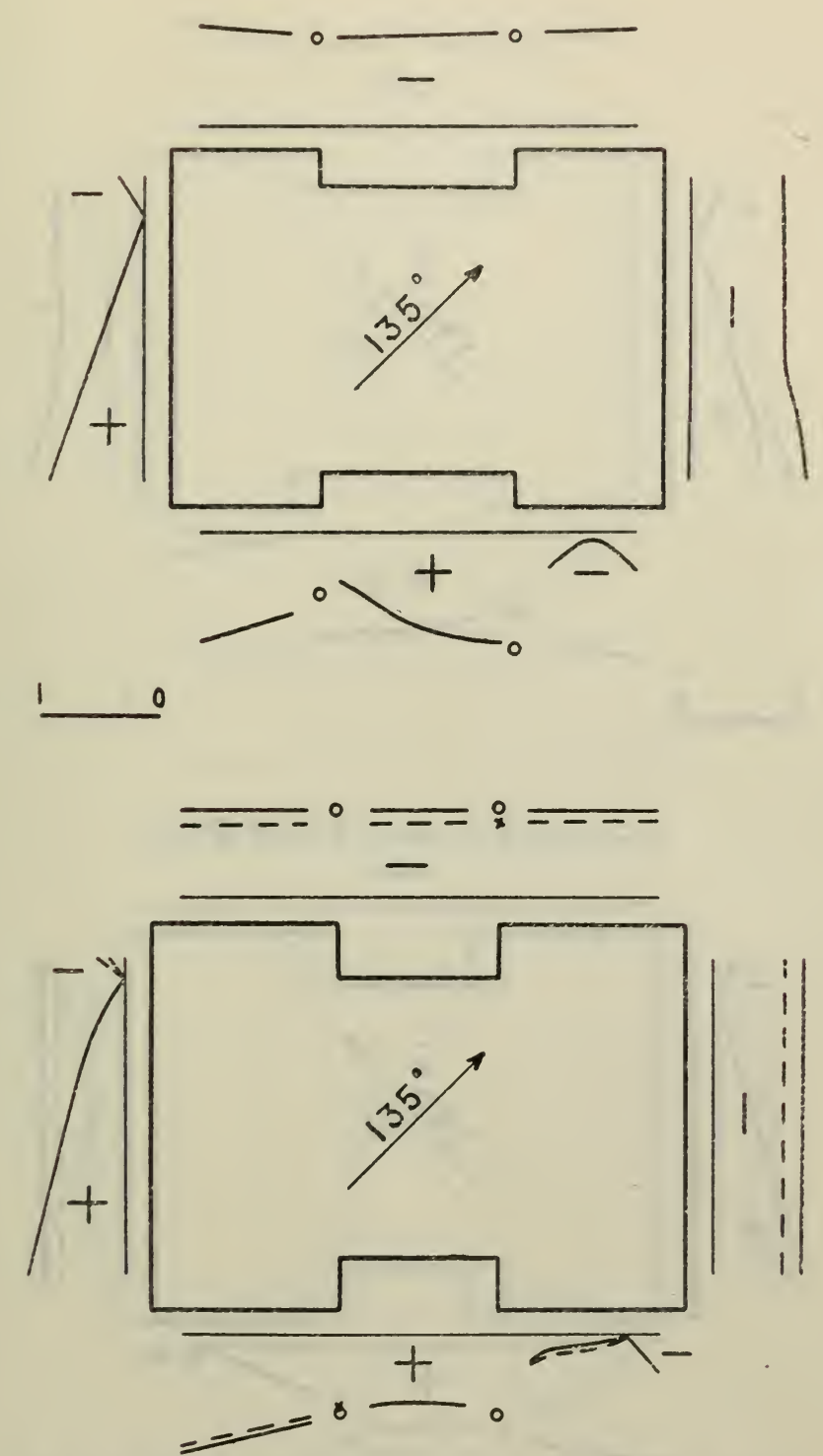

FIgURE 11.-Distribution of pressure at sections $A, B$, and $C$ at $135^{\circ}$ to the wind

See legend of Figure 6 

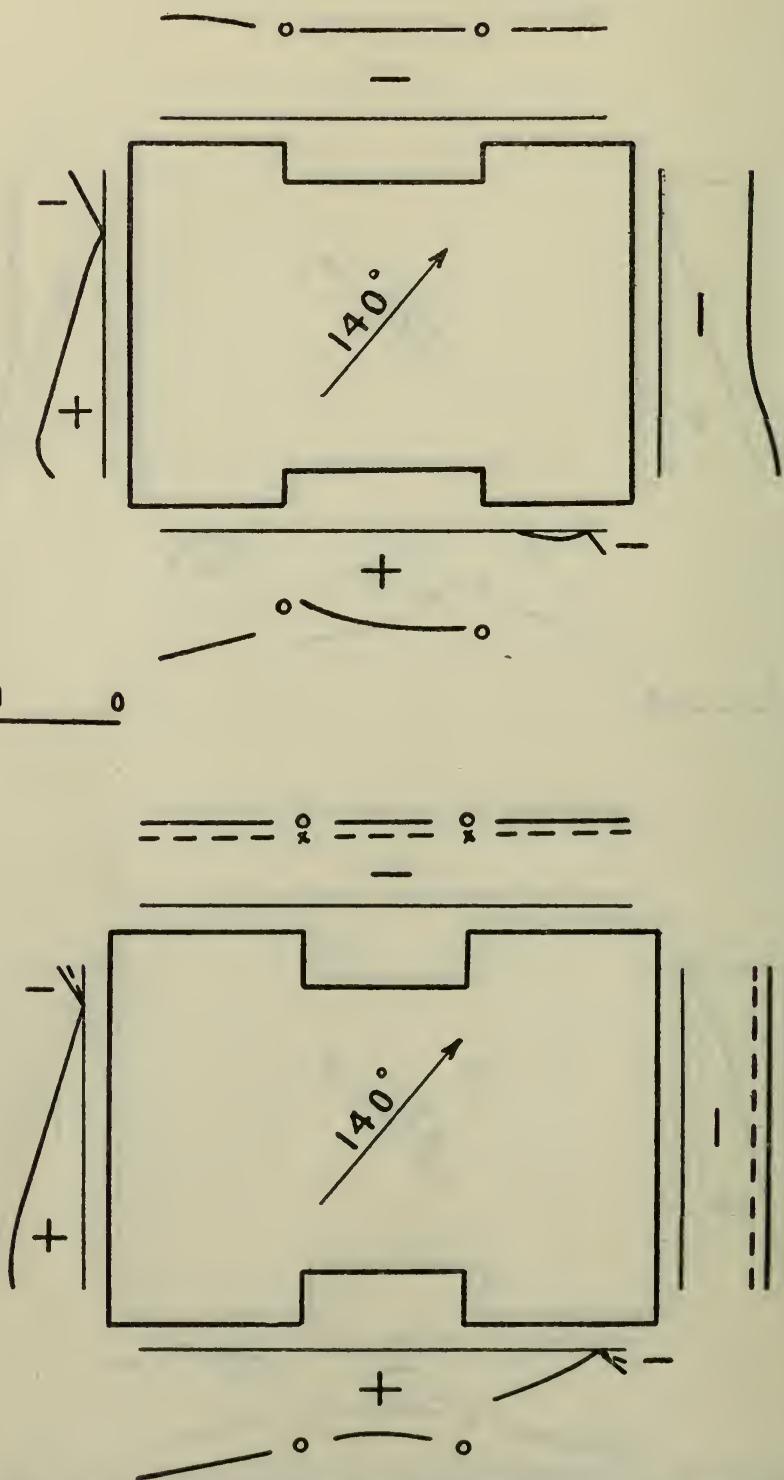

FIgURE 12.-Distribution of pressure at sections $A, B$, and $C$ at $140^{\circ}$ to the wind

See legend of Figure 6 

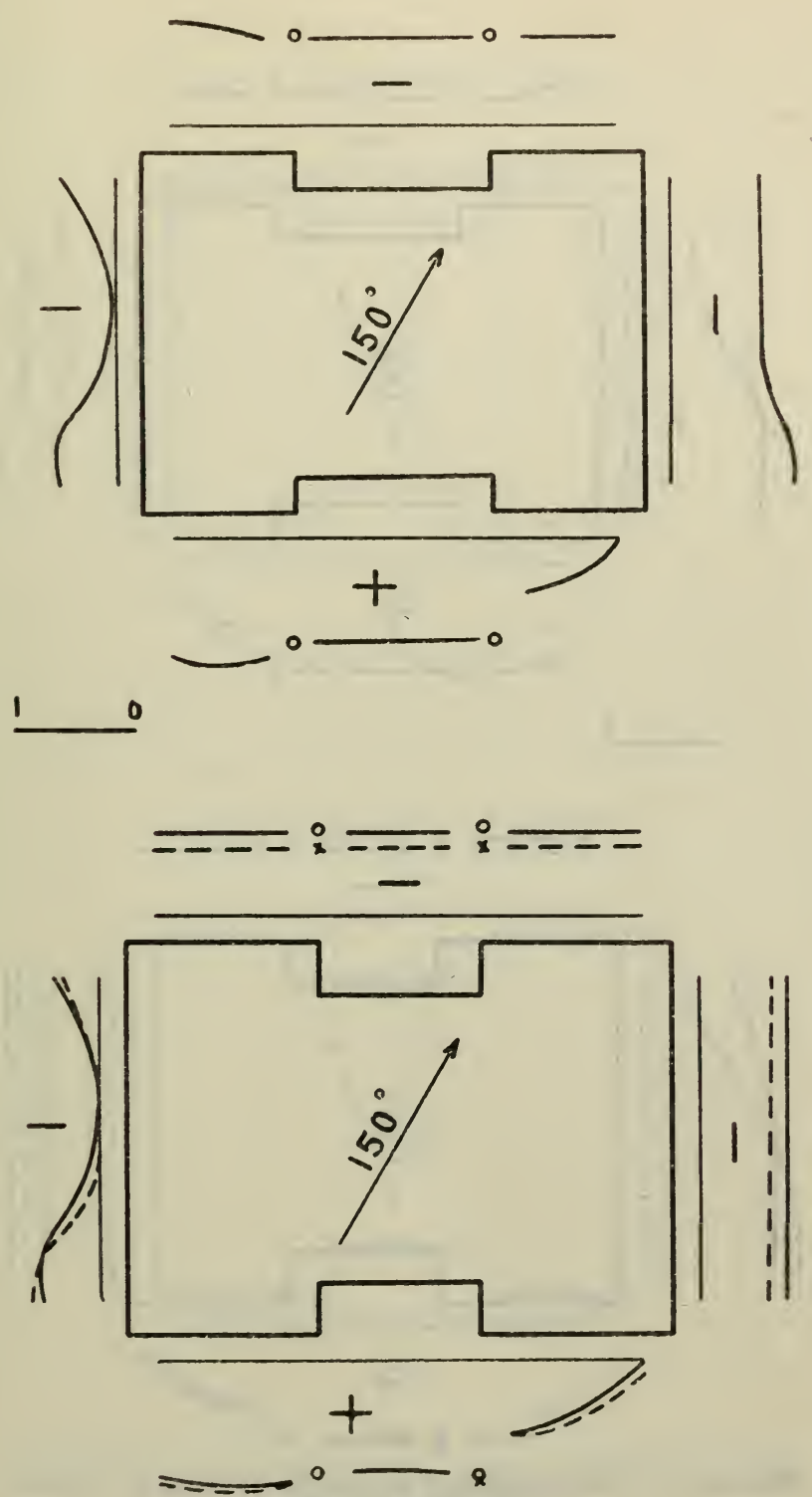

FIGURE 13.-Distribution of pressure at sections $A, B$, and $C$ at $150^{\circ}$ to the wind

See legend of Figure 6 

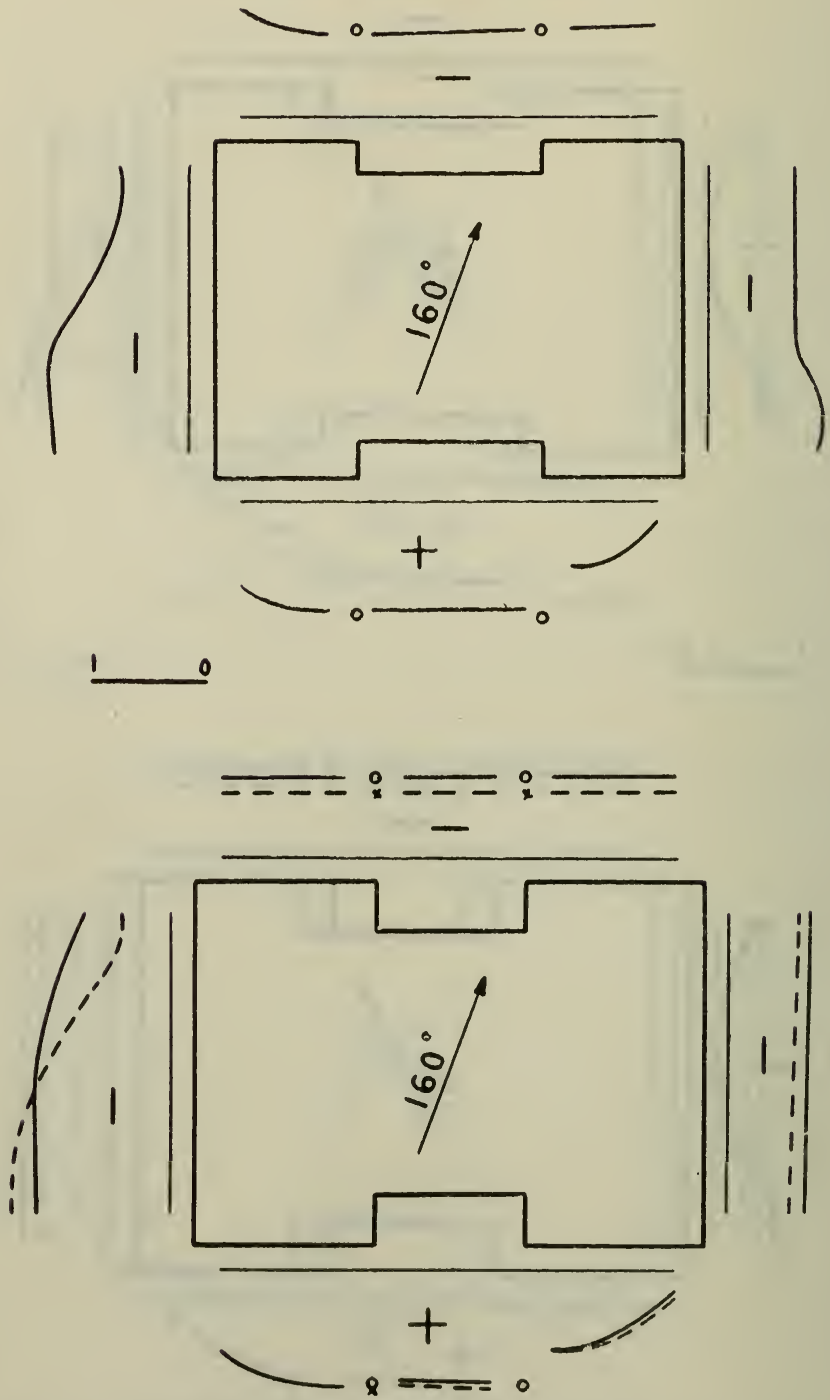

FIgURE 14.-Distribution of pressure at sections $A, B$, and $C$ at $160^{\circ}$ to the wind

See legend of Figure 6 

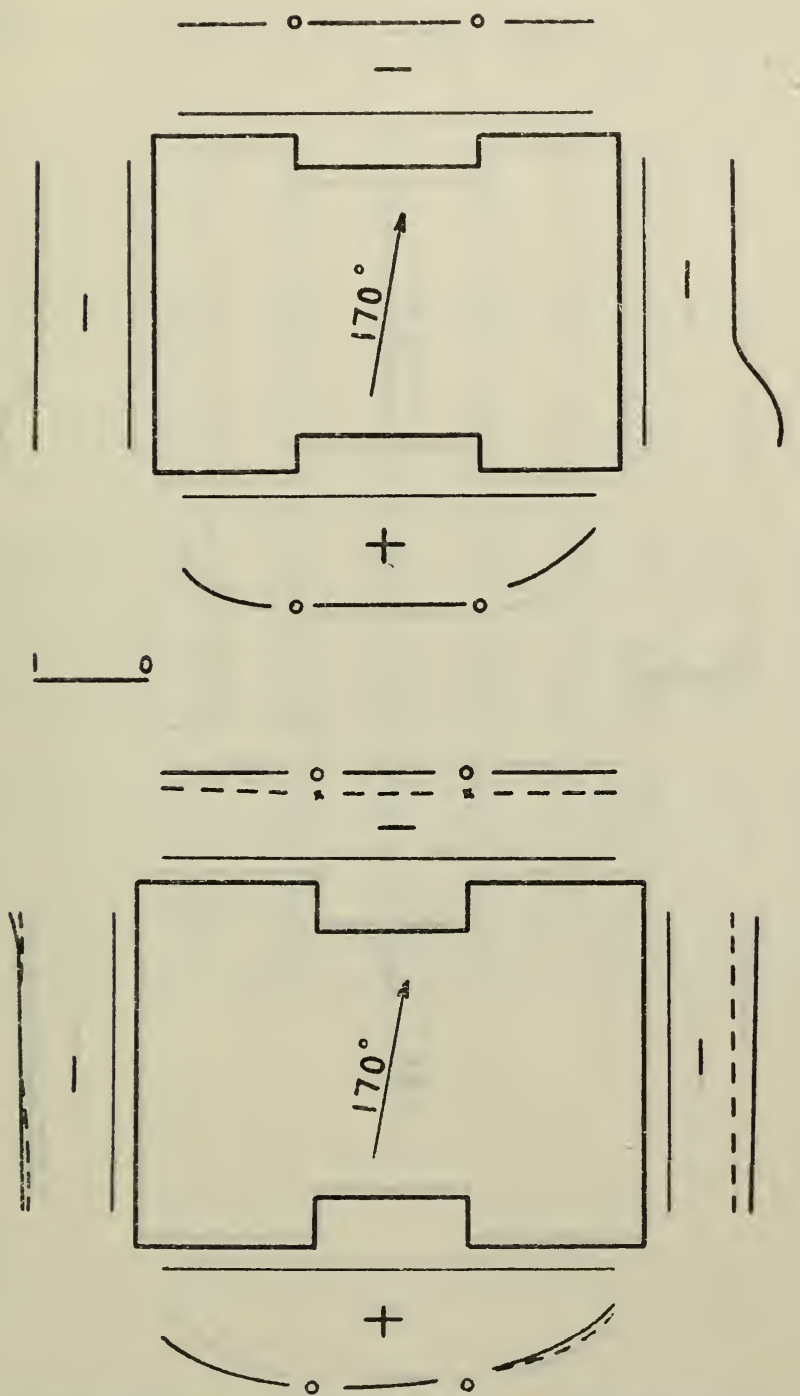

Figdre 15.-Distribution of pressure at sections $A, B$, and $C$ at $170^{\circ}$ to the wind

See legend of Figure 6 

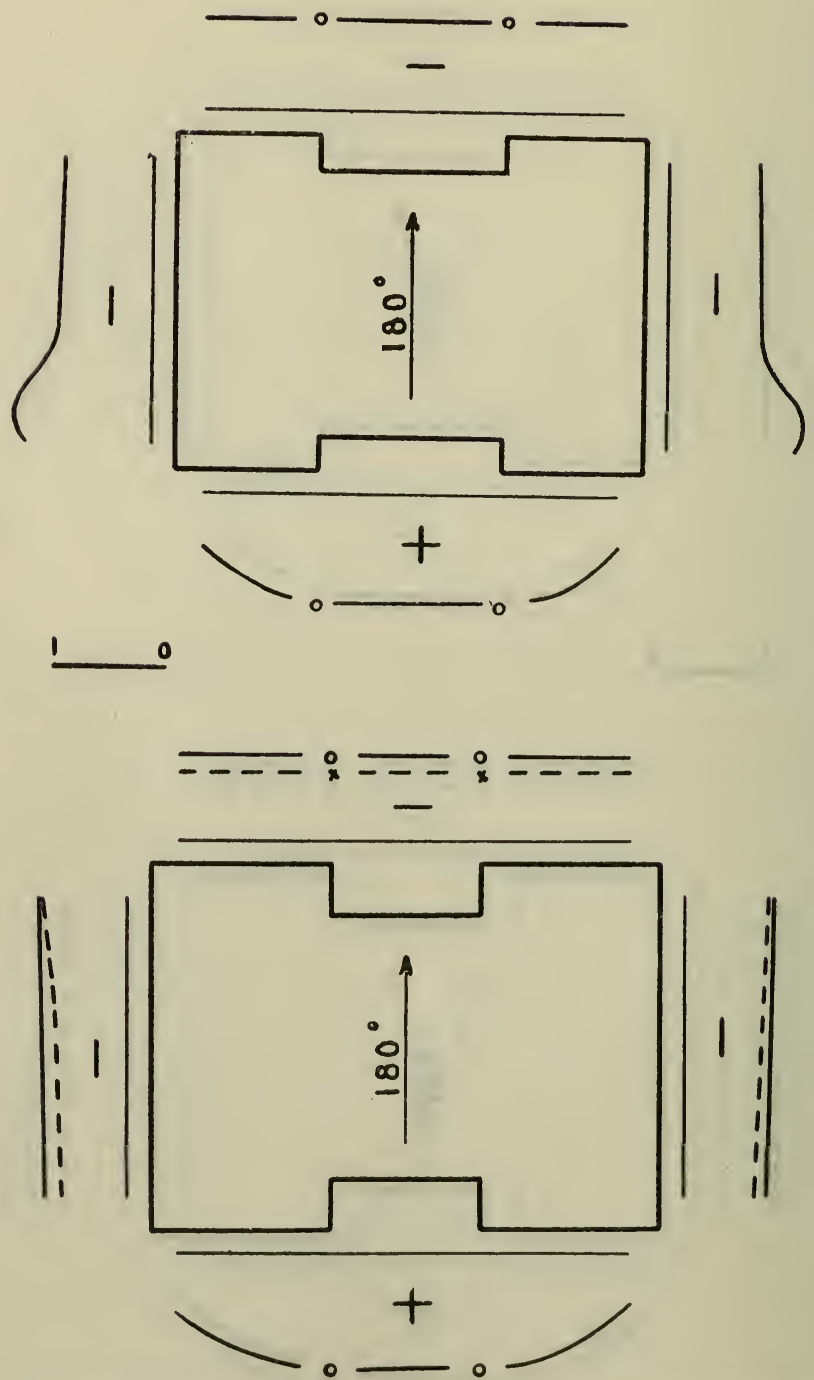

Figure 16.-Distribution of pressure at sections $A, B$, and $C$ at $180^{\circ}$ to the wind

See legend of Figure 6 
TABLE 3.-Pressure distribution over model, at various angles to the wind

(See figs. 2, 3, and 4 for position of holes and sections)

$p_{\bullet} / q$

Hole No.

\begin{tabular}{|c|c|c|c|c|c|c|c|c|}
\hline \multicolumn{3}{|c|}{$90^{\circ}$} & \multicolumn{3}{|c|}{$100^{\circ}$} & \multicolumn{3}{|c|}{$110^{\circ}$} \\
\hline $\begin{array}{c}\text { Sec- } \\
\text { tion } \\
A\end{array}$ & $\begin{array}{c}\text { Sec- } \\
\text { tion } \\
B\end{array}$ & $\begin{array}{c}\text { Sec- } \\
\text { tion } \\
C\end{array}$ & $\begin{array}{c}\text { Sec- } \\
\text { tion } \\
A\end{array}$ & $\begin{array}{l}\text { Sec- } \\
\text { tion } \\
B\end{array}$ & $\begin{array}{l}\text { Sec- } \\
\text { tion } \\
C\end{array}$ & $\begin{array}{l}\text { Sec- } \\
\text { tion } \\
A\end{array}$ & $\begin{array}{c}\text { Sec- } \\
\text { tion } \\
B\end{array}$ & $\begin{array}{c}\text { Sec } \\
\text { tion } \\
C^{\prime}\end{array}$ \\
\hline $\begin{array}{r}0.52 \\
.82 \\
.98 \\
.98 \\
.82\end{array}$ & $\begin{array}{r}0.66 \\
.89 \\
1.05 \\
1.05 \\
.89\end{array}$ & $\begin{array}{r}0.61 \\
.83 \\
.99 \\
.99 \\
.83\end{array}$ & $\begin{array}{r}0.62 \\
.89 \\
.98 \\
.92 \\
.69\end{array}$ & $\begin{array}{r}0.72 \\
.93 \\
1.03 \\
.96 \\
.77\end{array}$ & $\begin{array}{r}0.71 \\
.95 \\
1.03 \\
1.00 \\
.81\end{array}$ & $\begin{array}{r}0.84 \\
1.00 \\
.97 \\
.83 \\
.52\end{array}$ & $\begin{array}{r}0.91 \\
1.02 \\
1.01 \\
.89 \\
.64\end{array}$ & $\begin{array}{r}0.91 \\
1.05 \\
1.03 \\
.89 \\
.64\end{array}$ \\
\hline $\begin{array}{r}.56 \\
-.89 \\
-.94 \\
-.85 \\
-.75\end{array}$ & $\begin{array}{r}.66 \\
-.70 \\
-.68 \\
-.68 \\
-.69\end{array}$ & $\begin{array}{r}.63 \\
-.67 \\
-.68 \\
-.70 \\
-.68\end{array}$ & $\begin{array}{r}.42 \\
-.87 \\
-.81 \\
-.83 \\
-.73\end{array}$ & $\begin{array}{r}.44 \\
-.62 \\
-.60 \\
-61 \\
-.60\end{array}$ & $\begin{array}{r}.57 \\
-.51 \\
-.52 \\
-.52 \\
-.50\end{array}$ & $\begin{array}{r}.24 \\
-.93 \\
-.92 \\
-.76 \\
-.71\end{array}$ & $\begin{array}{r}.38 \\
-.60 \\
-.62 \\
-.63 \\
-.63\end{array}$ & $\begin{array}{r}.42 \\
-.50 \\
-.51 \\
-.52 \\
-.52\end{array}$ \\
\hline $\begin{array}{l}-.79 \\
-.78 \\
-.80 \\
-.78 \\
-.81\end{array}$ & $\begin{array}{l}-.70 \\
-.73 \\
-.73 \\
-.71 \\
-.72\end{array}$ & $\begin{array}{l}-.69 \\
-.71 \\
-.64 \\
-.63 \\
-.66\end{array}$ & $\begin{array}{l}-.76 \\
-.77 \\
-.76 \\
-.73 \\
-.77\end{array}$ & $\begin{array}{l}-.62 \\
-.64 \\
-.64 \\
-.61 \\
-.62\end{array}$ & $\begin{array}{l}-.53 \\
-.54 \\
-.55 \\
-.53 \\
-.56\end{array}$ & $\begin{array}{l}-.70 \\
-.72 \\
-.73 \\
-.70 \\
-.75\end{array}$ & $\begin{array}{l}-.62 \\
-.63 \\
-.63 \\
-.62 \\
-.63\end{array}$ & $\begin{array}{l}-.53 \\
-.55 \\
-.52 \\
-.51 \\
-.53\end{array}$ \\
\hline $\begin{array}{l}-.82 \\
-.83 \\
-.76 \\
-.75 \\
-.75\end{array}$ & $\begin{array}{l}-.77 \\
-.84 \\
-.60 \\
-.58 \\
-.57\end{array}$ & $\begin{array}{l}-.71 \\
-.73 \\
-.58 \\
-.56 \\
-.53\end{array}$ & $\begin{array}{l}-.78 \\
-.79 \\
-.74 \\
-.74 \\
-.75\end{array}$ & $\begin{array}{l}-.65 \\
-.67 \\
-.58 \\
-.58 \\
-.58\end{array}$ & $\begin{array}{l}-.58 \\
-.61 \\
-.46 \\
-.45 \\
-.45\end{array}$ & $\begin{array}{l}-.75 \\
-.75 \\
-.77 \\
-.75 \\
-.75\end{array}$ & $\begin{array}{l}-.83 \\
=.64 \\
=.62 \\
=.80 \\
-.60\end{array}$ & $\begin{array}{l}-.55 \\
-.58 \\
-.55 \\
-.55 \\
-.55\end{array}$ \\
\hline $\begin{array}{l}-.75 \\
-.76 \\
-.76 \\
-.79 \\
-.78\end{array}$ & $\begin{array}{l}-.57 \\
-.59 \\
-.65 \\
-.82 \\
-.76\end{array}$ & $\begin{array}{l}-.54 \\
-.56 \\
-.60 \\
-.80 \\
-.76\end{array}$ & $\begin{array}{l}-.75 \\
-.76 \\
-.78 \\
-.70 \\
-.75\end{array}$ & $\begin{array}{l}-.60 \\
-.60 \\
-.83 \\
-.77 \\
-.86\end{array}$ & $\begin{array}{l}-.46 \\
-.46 \\
-.49 \\
-.58 \\
-.71\end{array}$ & $\begin{array}{l}-.75 \\
-.80 \\
-.80 \\
-.50 \\
-.41\end{array}$ & $\begin{array}{l}-.62 \\
-.60 \\
-.61 \\
-.46 \\
-.39\end{array}$ & $\begin{array}{l}-.55 \\
-.54 \\
-.48 \\
-.32 \\
-.15\end{array}$ \\
\hline $\begin{array}{l}-.78 \\
-.78 \\
-.78 \\
-.78 \\
-.75\end{array}$ & $\begin{array}{l}-.71 \\
-.70 \\
-.72 \\
-.72 \\
-.69\end{array}$ & $\begin{array}{l}-.72 \\
-.70 \\
-.71 \\
-.71 \\
-.60\end{array}$ & $\begin{array}{r}-.88 \\
-1.08 \\
-1.03 \\
-1.08 \\
-1.05\end{array}$ & $\begin{array}{l}-.94 \\
-.97 \\
-.96 \\
-.97 \\
-.94\end{array}$ & $\begin{array}{r}-.86 \\
-1.05 \\
-.98 \\
-.87 \\
-.97\end{array}$ & $\begin{array}{l}-.40 \\
-.20 \\
-.16 \\
-.45 \\
-.46\end{array}$ & $\begin{array}{l}-.41 \\
-.54 \\
-.58 \\
-.62 \\
-.58\end{array}$ & $\begin{array}{l}-.09 \\
-.32 \\
-.38 \\
-.62 \\
-.55\end{array}$ \\
\hline $\begin{array}{l}-.78 \\
-.83 \\
-.81 \\
-.85\end{array}$ & $\begin{array}{l}-.69 \\
-.67 \\
-.66 \\
-.65\end{array}$ & $\begin{array}{l}-.60 \\
-.60 \\
-.59 \\
-.58\end{array}$ & $\begin{array}{l}-1.05 \\
-1.23 \\
-1.18 \\
-1.15\end{array}$ & $\begin{array}{l}-.93 \\
-.93 \\
-.91 \\
-.90\end{array}$ & $\begin{array}{r}-.93 \\
-1.08 \\
-1.05 \\
-1.03\end{array}$ & $\begin{array}{l}-.39 \\
-.71 \\
-.68 \\
-.63\end{array}$ & $\begin{array}{l}-.56 \\
-.65 \\
-.67 \\
-.65\end{array}$ & $\begin{array}{l}-.40 \\
-.76 \\
-.78 \\
-.77\end{array}$ \\
\hline
\end{tabular}


TABLE 4.--Pressure distribution over model, at various angles to the wind

(See figs. 2, 3, and 4 for position of holes and sections)

\begin{tabular}{|c|c|c|c|c|c|c|c|c|c|}
\hline \multirow{2}{*}{ Hole No. } & \multicolumn{3}{|c|}{$120^{\circ}$} & \multicolumn{3}{|c|}{$130^{\circ}$} & \multicolumn{3}{|c|}{$135^{\circ}$} \\
\hline & $\begin{array}{c}\text { Section } \\
A\end{array}$ & $\begin{array}{c}\text { Scetion } \\
B\end{array}$ & $\begin{array}{c}\text { Section } \\
C\end{array}$ & $\begin{array}{c}\text { Section } \\
A\end{array}$ & $\underset{B}{\text { Section }}$ & $\begin{array}{c}\text { Section } \\
C\end{array}$ & $\begin{array}{c}\text { Section } \\
A\end{array}$ & $\begin{array}{c}\text { Section } \\
B\end{array}$ & $\begin{array}{c}\text { Section } \\
C\end{array}$ \\
\hline $\begin{array}{l}1 \\
2 \\
3 \\
4 \\
5\end{array}$ & \begin{tabular}{r|}
1.02 \\
1.03 \\
.87 \\
.66 \\
.33
\end{tabular} & $\begin{array}{r}1.00 \\
1.00 \\
.90 \\
.70 \\
.40\end{array}$ & $\begin{array}{r}0.99 \\
1.00 \\
.89 \\
.69 \\
.43\end{array}$ & $\begin{array}{r}0.95 \\
.86 \\
.64 \\
.43 \\
.13\end{array}$ & $\begin{array}{r}1.02 \\
.91 \\
.73 \\
.52 \\
.22\end{array}$ & $\begin{array}{r}0.98 \\
.91 \\
.69 \\
.50 \\
.22\end{array}$ & $\begin{array}{l}0.80 \\
.69 \\
.49 \\
.28 \\
0\end{array}$ & $\begin{array}{r}0.83 \\
.74 \\
.57 \\
.37 \\
.09\end{array}$ & $\begin{array}{r}0.82 \\
.74 \\
.54 \\
.34 \\
.09\end{array}$ \\
\hline $\begin{array}{l}6 \\
7 \\
8 \\
9 \\
10\end{array}$ & $\begin{array}{r}.04 \\
-.96 \\
-.90 \\
-.78 \\
-.74\end{array}$ & $\begin{array}{r}.17 \\
-.68 \\
-.66 \\
-.66 \\
-.69\end{array}$ & $\begin{array}{r}.22 \\
-.50 \\
-.50 \\
-.52 \\
-.51\end{array}$ & $\begin{array}{l}-.12 \\
-.80 \\
-.80 \\
-.73 \\
-.69\end{array}$ & $\begin{array}{l}-.07 \\
-.68 \\
-.67 \\
-.68 \\
-.68\end{array}$ & $\begin{array}{r}.02 \\
-.53 \\
-.53 \\
-.54 \\
-.51\end{array}$ & $\begin{array}{l}-.22 \\
-.83 \\
-.82 \\
-.77 \\
-.73\end{array}$ & $\begin{array}{l}-.14 \\
-.73 \\
-.71 \\
-.71 \\
-.71\end{array}$ & $\begin{array}{l}-.24 \\
=.58 \\
=.58 \\
-.60 \\
-.72\end{array}$ \\
\hline $\begin{array}{l}11 \\
12 \\
13 \\
15\end{array}$ & $\begin{array}{l}-.74 \\
-.75 \\
-.74 \\
-.73 \\
-.76\end{array}$ & $\begin{array}{l}-.67 \\
-.69 \\
-.68 \\
-.70 \\
-.68\end{array}$ & $\begin{array}{l}-.53 \\
-.55 \\
-.56 \\
-.51 \\
-.56\end{array}$ & $\begin{array}{l}-.71 \\
-.73 \\
-.71 \\
-.69 \\
-.73\end{array}$ & $\begin{array}{l}-.69 \\
-.70 \\
-.70 \\
-.71 \\
-.70\end{array}$ & $\begin{array}{l}-.54 \\
-.56 \\
-.58 \\
-.57 \\
-.57\end{array}$ & $\begin{array}{l}-.75 \\
-.76 \\
-.76 \\
-.74 \\
-.77\end{array}$ & $\begin{array}{l}-.72 \\
-.72 \\
-.73 \\
-.74 \\
-.73\end{array}$ & $\begin{array}{l}-.58 \\
-.60 \\
-.64 \\
-.62 \\
-.63\end{array}$ \\
\hline $\begin{array}{l}16 \\
18 \\
19 \\
20\end{array}$ & $\begin{array}{l}-.77 \\
-.79 \\
-.76 \\
-.75 \\
-.76\end{array}$ & $\begin{array}{l}-.70 \\
-.72 \\
-.69 \\
-.69 \\
-.70\end{array}$ & $\begin{array}{l}-.58 \\
-.60 \\
-.50 \\
-.50 \\
-.50\end{array}$ & $\begin{array}{l}-.75 \\
-.75 \\
-.74 \\
-.73 \\
-.73\end{array}$ & $\begin{array}{l}-.71 \\
-.72 \\
-.69 \\
-.68 \\
-.68\end{array}$ & $\begin{array}{l}-.57 \\
-.57 \\
-.53 \\
-.52 \\
-.52\end{array}$ & $\begin{array}{l}-.78 \\
-.79 \\
-.78 \\
-.77 \\
-.77\end{array}$ & $\begin{array}{l}-.74 \\
-.74 \\
-.76 \\
-.75 \\
-.74\end{array}$ & $\begin{array}{l}-.63 \\
-.64 \\
-.59 \\
-.59 \\
-.58\end{array}$ \\
\hline $\begin{array}{l}21 \\
22 \\
24\end{array}$ & $\begin{array}{l}-.77 \\
-.87 \\
-.91 \\
-.48 \\
-.30\end{array}$ & $\begin{array}{l}-.70 \\
-.69 \\
-.70 \\
-.44 \\
-.22\end{array}$ & $\begin{array}{l}-.49 \\
-.48 \\
-.49 \\
-.30 \\
-.11\end{array}$ & $\begin{array}{l}-.74 \\
-.87 \\
-.91 \\
-.33 \\
-.08\end{array}$ & $\begin{array}{l}-.67 \\
-.66 \\
-.70 \\
-.30 \\
-.02\end{array}$ & $\begin{array}{r}-.52 \\
-.52 \\
-.52 \\
-.21 \\
.05\end{array}$ & $\begin{array}{l}-.79 \\
-.94 \\
-.98 \\
-.29 \\
-.03\end{array}$ & $\begin{array}{l}-.74 \\
-.73 \\
-.73 \\
-.29 \\
.06\end{array}$ & $\begin{array}{l}-.58 \\
-.57 \\
-.56 \\
-.31 \\
.12\end{array}$ \\
\hline $\begin{array}{l}26 \\
27 \\
28 \\
29 \\
30\end{array}$ & $\begin{array}{r}-.33 \\
.72 \\
.56 \\
.26 \\
.11\end{array}$ & $\begin{array}{r}-.13 \\
.29 \\
.19 \\
.15 \\
.18\end{array}$ & $\begin{array}{r}-.04 \\
.31 \\
.22 \\
.17 \\
.21\end{array}$ & $\begin{array}{r}-.40 \\
.99 \\
.83 \\
.54 \\
.40\end{array}$ & $\begin{array}{l}.10 \\
.52 \\
.44 \\
.43 \\
.47\end{array}$ & $\begin{array}{l}.16 \\
.55 \\
.45 \\
.41 \\
.46\end{array}$ & $\begin{array}{r}-.28 \\
.97 \\
.89 \\
.77 \\
.42\end{array}$ & $\begin{array}{l}.22 \\
.67 \\
.58 \\
.56 \\
.59\end{array}$ & $\begin{array}{l}.25 \\
.67 \\
.59 \\
.56 \\
.56\end{array}$ \\
\hline $\begin{array}{l}31 \ldots \\
32 \ldots- \\
33 \ldots \\
34 \ldots\end{array}$ & $\begin{array}{r}.13 \\
.25 \\
.16 \\
-.11\end{array}$ & $\begin{array}{r}.22 \\
.28 \\
.13 \\
-.10\end{array}$ & $\begin{array}{r}.26 \\
.31 \\
.05 \\
-.12\end{array}$ & $\begin{array}{l}.38 \\
.55 \\
.67 \\
.79\end{array}$ & $\begin{array}{l}.50 \\
.58 \\
.68 \\
.83\end{array}$ & $\begin{array}{l}.51 \\
.58 \\
.69 \\
.82\end{array}$ & $\begin{array}{l}.51 \\
.65 \\
.78 \\
.91\end{array}$ & $\begin{array}{l}.65 \\
.70 \\
.84 \\
.98\end{array}$ & $\begin{array}{l}.62 \\
.69 \\
.81 \\
.93\end{array}$ \\
\hline
\end{tabular}


TABLE 5.-Pressure distribution over model, at various angles to the wind

(See figs. 2,3 , and 4 for position of holes and sections)

$p_{u} / a$

\begin{tabular}{|c|c|c|c|c|c|c|c|c|c|}
\hline \multirow{2}{*}{ Hole No. } & \multicolumn{3}{|c|}{$140^{\circ}$} & \multicolumn{3}{|c|}{$150^{\circ}$} & \multicolumn{3}{|c|}{$160^{\circ}$} \\
\hline & $\begin{array}{l}\text { Sec- } \\
\text { tion } \\
A\end{array}$ & $\begin{array}{c}\text { Sec- } \\
\text { tion } \\
B\end{array}$ & $\begin{array}{l}\text { Sec- } \\
\text { tion } \\
C\end{array}$ & $\begin{array}{l}\text { Sec- } \\
\text { tion } \\
A\end{array}$ & $\begin{array}{c}\text { Sec- } \\
\text { tion } \\
B\end{array}$ & $\begin{array}{l}\text { Sec- } \\
\text { tion } \\
C\end{array}$ & $\begin{array}{l}\text { Sec- } \\
\text { tion } \\
A\end{array}$ & $\begin{array}{c}\text { Sec- } \\
\text { tion } \\
\qquad 5\end{array}$ & $\begin{array}{l}\text { Sec- } \\
\text { tion } \\
C\end{array}$ \\
\hline 1. & $\begin{array}{r}0.39 \\
.55 \\
.36 \\
.17 \\
-.10\end{array}$ & $\begin{array}{r}0.57 \\
.58 \\
.42 \\
.22 \\
-.01\end{array}$ & $\begin{array}{l}0.55 \\
.59 \\
.40 \\
.22 \\
.01\end{array}$ & $\begin{array}{l}-0.48 \\
-.51 \\
-.13 \\
-.04 \\
-.26\end{array}$ & $\begin{array}{r}-0.46 \\
-.49 \\
-.13 \\
.02 \\
-.19\end{array}$ & $\begin{array}{r}-0.56 \\
-.51 \\
.03 \\
-.02 \\
-.19\end{array}$ & $\begin{array}{l}-1.15 \\
-1.22 \\
-1.23 \\
-.82 \\
-.55\end{array}$ & $\begin{array}{l}-1.16 \\
-1.16 \\
-1.18 \\
-1.11 \\
-.90\end{array}$ & $\begin{array}{l}-1.37 \\
-1.35 \\
-1.22 \\
-.88 \\
-.47\end{array}$ \\
\hline $\begin{array}{l}6 \ldots . . \\
8 \\
9 \\
9 \\
10 \ldots\end{array}$ & $\begin{array}{l}-.30 \\
-.80 \\
-.79 \\
-.74 \\
-.71\end{array}$ & $\begin{array}{l}-.20 \\
-.67 \\
-.67 \\
-.67 \\
-.68\end{array}$ & $\begin{array}{l}-.15 \\
-.54 \\
-.54 \\
-.56 \\
-.54\end{array}$ & $\begin{array}{l}-.45 \\
-.84 \\
-.79 \\
-.72 \\
-.72\end{array}$ & $\begin{array}{l}-.35 \\
-.68 \\
-.66 \\
-.66 \\
-.68\end{array}$ & $\begin{array}{l}-.29 \\
-.54 \\
-.55 \\
-.56 \\
-.53\end{array}$ & $\begin{array}{l}-.60 \\
-.93 \\
-.75 \\
-.70 \\
-.76\end{array}$ & $\begin{array}{l}-.73 \\
-.66 \\
-.68 \\
-.68 \\
-.68\end{array}$ & $\begin{array}{l}-.42 \\
-.55 \\
-.56 \\
-.55 \\
-.55\end{array}$ \\
\hline $\begin{array}{l}11 \ldots \ldots \\
12 \\
13 \\
15\end{array}$ & $\begin{array}{l}-.71 \\
-.73 \\
-.71 \\
-.70 \\
-.72\end{array}$ & $\begin{array}{l}-.67 \\
-.68 \\
-.68 \\
-.71 \\
-.68\end{array}$ & $\begin{array}{l}-.53 \\
-.54 \\
-.58 \\
-.56 \\
-.57\end{array}$ & $\begin{array}{l}-.71 \\
-.73 \\
-.73 \\
-.74 \\
-.73\end{array}$ & $\begin{array}{l}-.67 \\
-.67 \\
-.68 \\
-.69 \\
-.67\end{array}$ & $\begin{array}{l}-.54 \\
-.54 \\
-.56 \\
-.57 \\
-.56\end{array}$ & $\begin{array}{l}-.69 \\
-.71 \\
-.76 \\
-.76 \\
-.76\end{array}$ & $\begin{array}{l}-.70 \\
-.68 \\
-.69 \\
-.71 \\
-.69\end{array}$ & $\begin{array}{l}-.53 \\
-.52 \\
-.55 \\
-.56 \\
-.57\end{array}$ \\
\hline 16 & $\begin{array}{l}-.73 \\
-.73 \\
-.73 \\
-.73 \\
-.72\end{array}$ & $\begin{array}{l}-.69 \\
-.70 \\
-.72 \\
-.71 \\
-.69\end{array}$ & $\begin{array}{l}-.57 \\
-.58 \\
-.57 \\
-.57 \\
-.57\end{array}$ & $\begin{array}{l}-.74 \\
-.73 \\
-.74 \\
-.73 \\
-.73\end{array}$ & $\begin{array}{l}-.67 \\
-.68 \\
-.71 \\
-.70 \\
-.68\end{array}$ & $\begin{array}{l}-.56 \\
-.56 \\
-.58 \\
-.57 \\
-.55\end{array}$ & $\begin{array}{l}-.76 \\
-.77 \\
-.76 \\
-.74 \\
-.75\end{array}$ & $\begin{array}{l}-.69 \\
-.69 \\
-.71 \\
-.71 \\
-.69\end{array}$ & $\begin{array}{l}-.57 \\
-.57 \\
-.63 \\
-.61 \\
-.58\end{array}$ \\
\hline $\begin{array}{l}21 \\
22 \\
24 \\
25\end{array}$ & $\begin{array}{l}-.75 \\
-.93 \\
-.97 \\
-.21 \\
.07\end{array}$ & $\begin{array}{r}-.69 \\
-.69 \\
-.69 \\
-.16 \\
.18\end{array}$ & $\begin{array}{l}-.56 \\
-.53 \\
-.53 \\
-.08 \\
.22\end{array}$ & $\begin{array}{r}-.76 \\
-1.00 \\
-1.02 \\
-.02 \\
.31\end{array}$ & $\begin{array}{r}-.68 \\
-.68 \\
-.69 \\
.01 \\
.40\end{array}$ & $\begin{array}{r}-.55 \\
-.53 \\
-.53 \\
.09 \\
.47\end{array}$ & $\begin{array}{r}-.77 \\
-1.01 \\
-.96 \\
.15 \\
.50\end{array}$ & $\begin{array}{r}-.69 \\
-.68 \\
-.66 \\
.18 \\
.58\end{array}$ & $\begin{array}{r}-.57 \\
-.54 \\
-.51 \\
.25 \\
.64\end{array}$ \\
\hline $\begin{array}{l}26 \\
27 \\
25 \\
29 \\
30\end{array}$ & $\begin{array}{l}.01 \\
.83 \\
.77 \\
.75 \\
.57\end{array}$ & $\begin{array}{l}.36 \\
.81 \\
.71 \\
.70 \\
.72\end{array}$ & $\begin{array}{l}.39 \\
.80 \\
.72 \\
.70 \\
.72\end{array}$ & $\begin{array}{l}.45 \\
.84 \\
.82 \\
.86 \\
.84\end{array}$ & $\begin{array}{l}.59 \\
.94 \\
.92 \\
.89 \\
.90\end{array}$ & $\begin{array}{r}.58 \\
1.00 \\
.93 \\
.90 \\
.94\end{array}$ & $\begin{array}{r}.57 \\
1.02 \\
.93 \\
.93 \\
.94\end{array}$ & $\begin{array}{r}.72 \\
1.01 \\
.99 \\
.99 \\
.96\end{array}$ & $\begin{array}{l}.70 \\
1.00 \\
1.04 \\
1.04 \\
.99\end{array}$ \\
\hline $\begin{array}{l}31 \\
32 \\
33 \\
34\end{array}$ & $\begin{array}{r}.62 \\
.82 \\
.94 \\
1.04\end{array}$ & $\begin{array}{r}.76 \\
.84 \\
.95 \\
1.05\end{array}$ & $\begin{array}{r}.78 \\
.85 \\
.95 \\
1.05\end{array}$ & $\begin{array}{r}.86 \\
.96 \\
1.01 \\
.96\end{array}$ & $\begin{array}{r}.92 \\
.98 \\
1.02 \\
.94\end{array}$ & $\begin{array}{r}.94 \\
1.02 \\
1.07 \\
.99\end{array}$ & $\begin{array}{l}.98 \\
.97 \\
.94 \\
.74\end{array}$ & $\begin{array}{r}.99 \\
1.03 \\
.98 \\
.72\end{array}$ & $\begin{array}{r}1.03 \\
1.02 \\
.99 \\
.69\end{array}$ \\
\hline
\end{tabular}


TABLE 6.-Pressure distribution over model, at various angles to the wind (See figs. 2, 3, and 4, for position of holes and sections)

\begin{tabular}{|c|c|c|c|c|c|c|}
\hline \multirow[b]{2}{*}{ Hole No. } & \multicolumn{3}{|c|}{$170^{\circ}$} & \multicolumn{3}{|c|}{$180^{\circ}$} \\
\hline & $\underset{A}{\text { Section }}$ & $\underset{B}{\text { Section }}$ & $\underset{C}{\text { Section }}$ & $\underset{A}{\text { Section }}$ & $\underset{B}{\text { Section }}$ & $\stackrel{\text { Section }}{C}$ \\
\hline $\begin{array}{l}1 \\
2 \\
3 \\
4\end{array}$ & $\begin{array}{l}-0.83 \\
-.85 \\
-.84 \\
-.81 \\
-.79\end{array}$ & $\begin{array}{l}-0.76 \\
-.77 \\
-.79 \\
-.80 \\
-.84\end{array}$ & $\begin{array}{l}-0.73 \\
-.74 \\
-.78 \\
-.81 \\
-.80\end{array}$ & $\begin{array}{r}-1.10 \\
-1.21 \\
-.84 \\
-.79 \\
-.79\end{array}$ & $\begin{array}{l}-0.74 \\
-.74 \\
-.75 \\
-.77 \\
-.80\end{array}$ & $\begin{array}{l}-0.58 \\
-.59 \\
-.62 \\
-.66 \\
-.72\end{array}$ \\
\hline 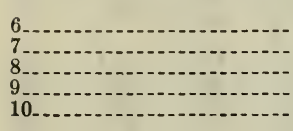 & $\begin{array}{l}-.81 \\
-.75 \\
=.75 \\
-.75 \\
-.79\end{array}$ & $\begin{array}{l}-.92 \\
=.74 \\
=.75 \\
=.74 \\
=.72\end{array}$ & $\begin{array}{l}-.83 \\
-.62 \\
-.58 \\
-.56 \\
-.54\end{array}$ & $\begin{array}{l}-.78 \\
-.79 \\
-.79 \\
-.79 \\
-.79\end{array}$ & $\begin{array}{l}-.80 \\
-.74 \\
=.72 \\
-.72 \\
-.71\end{array}$ & $\begin{array}{l}-.75 \\
-.60 \\
-.58 \\
-.57 \\
-.55\end{array}$ \\
\hline 11 11 13 & $\begin{array}{l}-.77 \\
=.78 \\
=.78 \\
-.80 \\
-.78\end{array}$ & $\begin{array}{l}-.72 \\
=.72 \\
=.74 \\
-.73 \\
-.73\end{array}$ & $\begin{array}{l}-.54 \\
-.54 \\
-.55 \\
-.56 \\
-.55\end{array}$ & $\begin{array}{l}-.80 \\
=.81 \\
=.78 \\
-.77 \\
-.79\end{array}$ & $\begin{array}{l}-.72 \\
-.72 \\
-.72 \\
-.72 \\
-.73\end{array}$ & $\begin{array}{l}-.57 \\
=.57 \\
=.56 \\
-.56 \\
-.57\end{array}$ \\
\hline $\begin{array}{l}16 \\
17 \\
18 \\
19 \\
20\end{array}$ & $\begin{array}{l}-.78 \\
-.78 \\
-.79 \\
-.79 \\
-.78\end{array}$ & $\begin{array}{l}-.74 \\
=.75 \\
-.76 \\
-.75 \\
-.75\end{array}$ & $\begin{array}{l}-.54 \\
=.56 \\
-.56 \\
-.55 \\
-.62\end{array}$ & $\begin{array}{l}-.79 \\
=.78 \\
=.79 \\
-.78 \\
-.78\end{array}$ & $\begin{array}{l}-.72 \\
=.73 \\
-.78 \\
-.78 \\
-.75\end{array}$ & $\begin{array}{l}-.57 \\
=.60 \\
=.73 \\
-.72 \\
-.68\end{array}$ \\
\hline $\begin{array}{l}21 \\
22 \\
23\end{array}$ & $\begin{array}{r}-.81 \\
-1.20 \\
-1.18 \\
.26 \\
.62\end{array}$ & $\begin{array}{r}-.73 \\
-.71 \\
-.71 \\
.29 \\
.71\end{array}$ & $\begin{array}{r}-.59 \\
-.56 \\
-.56 \\
.37 \\
.76\end{array}$ & $\begin{array}{r}-.82 \\
-1.18 \\
-1.14 \\
.42 \\
.75\end{array}$ & $\begin{array}{r}-.73 \\
-.71 \\
-.74 \\
.44 \\
.83\end{array}$ & $\begin{array}{r}-.64 \\
-.61 \\
-.59 \\
.49 \\
.85\end{array}$ \\
\hline 30 & $\begin{array}{l}.77 \\
.95 \\
.96 \\
.97 \\
.97\end{array}$ & $\begin{array}{l}.87 \\
1.04 \\
1.00 \\
1.01 \\
1.01\end{array}$ & $\begin{array}{l}.87 \\
1.03 \\
1.03 \\
1.03 \\
1.02\end{array}$ & $\begin{array}{l}.86 \\
.98 \\
.94 \\
.94 \\
.93\end{array}$ & $\begin{array}{l}.97 \\
1.04 \\
1.02 \\
1.02 \\
1.01\end{array}$ & $\begin{array}{l}.95 \\
1.02 \\
1.03 \\
1.03 \\
1.00\end{array}$ \\
\hline $\begin{array}{l}31 \\
32 \\
334 \\
34\end{array}$ & $\begin{array}{l}.96 \\
.96 \\
.88 \\
.63\end{array}$ & $\begin{array}{r}1.03 \\
1.02 \\
.93 \\
.63\end{array}$ & $\begin{array}{r}1.03 \\
1.01 \\
.94 \\
.64\end{array}$ & $\begin{array}{l}.96 \\
.86 \\
.73 \\
.44\end{array}$ & $\begin{array}{r}1.03 \\
.97 \\
.84 \\
.51\end{array}$ & $\begin{array}{l}1.02 \\
.95 \\
.84 \\
.51\end{array}$ \\
\hline
\end{tabular}

\section{DISCUSSION}

Some of the more striking features of the pressure distribution will be described for purposes of emphasis. The greater part of the model is under reduced pressure. The lee faces are subjected to a nearly constant reduced pressure, although the absolute pressure is usually higher at the lower elevation. A fine thread showed that the air passing over the top of the model was deflected downward and that a large eddy is formed behind the model extending downstream some 3 feet. Near the building on the lee side the current is upward as indicated by the pressure distribution.

The behaviour of the embrasures is of interest. In most cases the embrasures carry the pressure of the adjacent wall. When however the embrasure is on the windward side, the pressure is increased relative to that on the neighboring wall. This behaviour is perceptible in Figure 8 for $110^{\circ}$ and is very marked in Figure 11 for $135^{\circ}$, especially for elevation $A$.

When a face is struck directly by the wind (figs. 6 and 16), the pressure is greatest in the center, falling off toward the edges. The placing of wind bracing in the end panels alone does not seem to be the most suitable to withstand this type of loading. 


\section{MEASUREMENTS OF OVERTURNING MOMENT}

\section{APPARATUS AND METHOD}

In addition to measurements of the pressure distribution, the overturning moments were directly measured. For this purpose, the

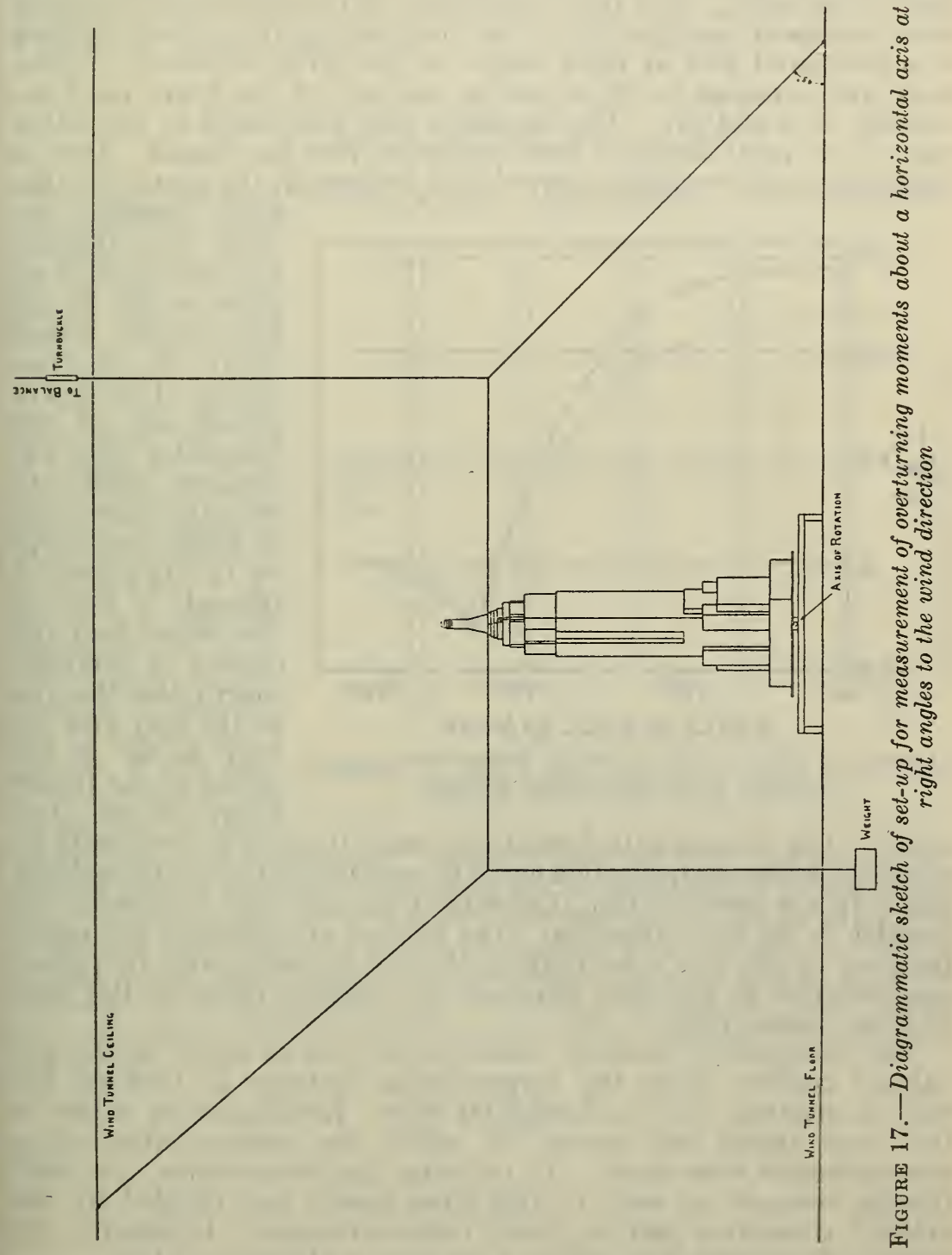

model and attached circular plate were placed on a horizontal bar 1 inch wide and one-half inch thick. The ends of the bar carried the inner races of ball bearings; the outer races of the bearings were supported in housings secured to the platform on the floor of the tunnel. The model and the circular plate could be rotated with 
respect to the bar about a vertical axis and held at any desired azimuth as in the pressure distribution tests. (Fig. 17.) For measuring the resultant overturning moment, it was necessary to measure the components about two horizontal axes, one parallel to the wind direction, the other at right angles to the wind direction, since, in general, the resultant force on the model has a component transverse to the direction of the wind. The two components of the overturning moment were measured separately. In the first set-up, the axis of rotation was horizontal and at right angles to the wind direction. A fine steel wire attached to the model at the base of the tower ran horizontally fore and aft. The upstream end was joined to two other wires at a point about 4 feet upstream from the model. One of these wires ran vertically upward to a balance in the room over the

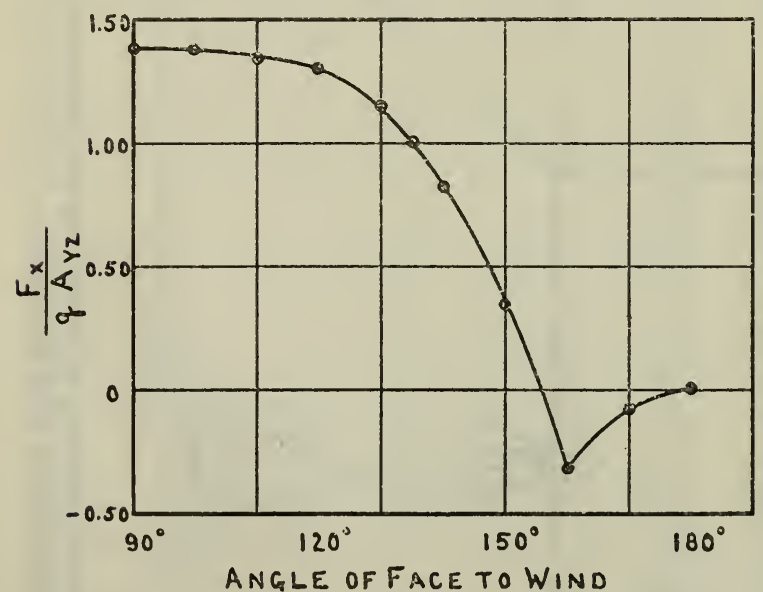

FIGURE 18.-The $x$-force coefficient derived from measurements of the overturning moment wind tunnel; the other ran forward and downward at an angle of $45^{\circ}$ to the floor of the tunnel where it was fastened. The downstream end of the horizontal wire was similarly joined to two other wires, one of which ran vertically downward through a hole in the tunnel floor and carried a counterweight; the other ran to the rear and upward at $45^{\circ}$ to the ceiling of the tunnel where it was fastened. The balance attachment was made through a turnbuckle by
means of which compensation could be made for motion of the balance pan. In the second set-up, the axis of rotation was horizontal and parallel to the wind direction. The balance arrangement was essentially as in the first set-up except that all the wires were in a plane perpendicular to the wind direction, the balance being on the right looking downstream.

The overturning moment about either axis is equal to the net balance reading times the perpendicular distance $h^{\prime}$ between the axis of rotation and the horizontal wire. Readings were taken at the same angles and speeds for which the pressure distribution measurements were made. In reducing the observations, the overturning moment at each of the three speeds was divided by the velocity pressure $q$ and the three values averaged. In general, the individual readings were within 2 per cent of the mean value.

\section{RESULTS}

The moments were measured about axes parallel and perpendicular to the wind direction, to make the balance arrangements as simple as possible. It is more convenient in practice to refer moments to the 
principal axes of the building, designated as in Figure 4 . (The $X$ axis is directed into the plane of the paper at right angles to the $Y$ and $Z$ axes and is parallel to the wind direction when the model setting is $90^{\circ}$.) At any given angle $\theta$ of the model, call $F_{D}{ }_{D}$ and $F_{C W}$ the net balance readings for measurements about the axes perpendicular and parallel to the wind, $F_{x}^{\prime}$ and $F_{y}^{\prime}$ the values which would have been observed if the wire and balance system had been placed in the $Y Z$ and $X Z$ planes, respectively. It is easily seen that

$$
\begin{aligned}
& F_{x}^{\prime}=F_{D} \cos \left(\theta-90^{\circ}\right)-F_{C W} \sin \left(\theta-90^{\circ}\right) \\
& F_{y}^{\prime}=F_{D} \sin \left(\theta-90^{\circ}\right)+F_{C W} \cos \left(\theta-90^{\circ}\right)
\end{aligned}
$$

For comparison with the pressure measurements, it is desirable to divide the overturning moments about the $X$ and $Y$ axes by the areas of the $Y Z$ and $X Z$ faces (designated $A_{y z}$ and $\left.A_{x z}\right)$ and by the distance from the line of action of the resultant force from the axis of rotation. This latter distance is however not known. A suitable conventional distance would be the distance $h$ from the axis to the center of gravity of the area of projection of the

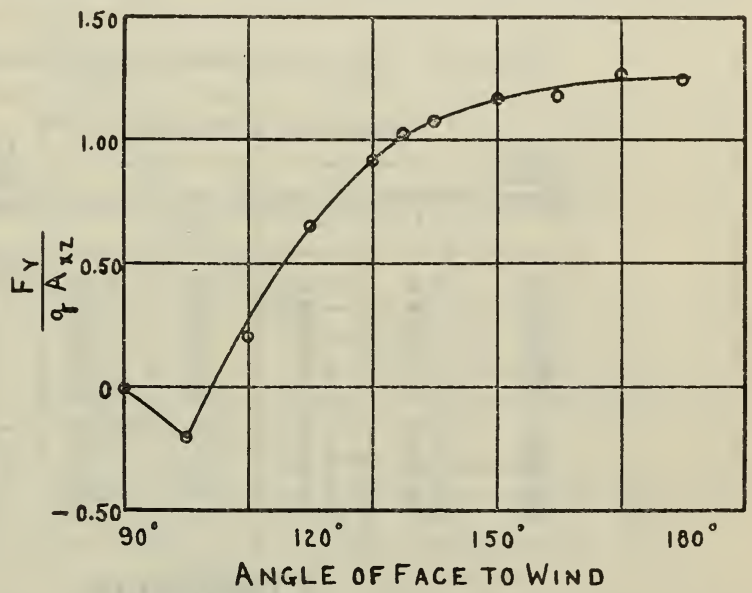

Figure 19.-The $y$-force coefficient derived from measurements of the overturning moment model on a plane

normal to the wind direction. This distance, however, varies with the angular setting from 25.07 inches at $90^{\circ}$ to 22.90 at $180^{\circ}$. The mean value is 23.98 inches or 1.998 feet. The results were finally expressed in terms of coefficients derived from fictitious forces $F_{x}$ and $F_{y}$ which if applied at the mean height $h$ of the center of area would give the observed overturning moments. The final coefficients given in the sixth column of Tables 7 and 8 and plotted in Figures 18 and 19 are defined by

and

$$
\frac{F_{x}}{q A_{y z}}=\frac{F_{x}^{\prime} h^{\prime}}{q h A_{y z}}
$$

$$
\frac{F_{y}}{q A_{x z}}=\frac{F_{y}{ }^{\prime} h^{\prime}}{q h A_{x z}}
$$

where for the model $h^{\prime}=4.413$ feet, $h=1.998$ feet, $A_{y z}=2.486 \mathrm{ft}^{2}$, $A_{x 2}=3.915 \mathrm{ft}^{2}{ }^{2}$. The overturning moments at a given velocity pressure may be obtained by multiplying the coefficients by the product of velocity pressure, projected area on the vertical plane containing the axis of rotation, and mean distance $h$ from the axis to the center of area. 
TABLE 7.-The $x$ components of the force coefficients

\begin{tabular}{|c|c|c|c|c|c|c|}
\hline $\begin{array}{c}\text { Angle of } \\
\text { wind } \\
\text { (degrees) }\end{array}$ & \multicolumn{3}{|c|}{ From pressure distribution data } & $\begin{array}{c}\text { From } \\
\text { over- } \\
\text { turning } \\
\text { moments }\end{array}$ & $\begin{array}{c}\text { Differ- } \\
\text { ence }\end{array}$ \\
\cline { 2 - 7 } & $\begin{array}{c}\text { Elevation } \\
\text { Elevation } \\
B\end{array}$ & $\begin{array}{r}\text { Elevation } \\
C\end{array}$ & Mean & \\
\hline 90 & 1.57 & 1.48 & 1.40 & 1.48 & 1.38 & 0.10 \\
100 & 1.54 & 1.42 & 1.31 & 1.42 & 1.37 & .05 \\
110 & 1.56 & 1.44 & 1.39 & 1.46 & 1.34 & .12 \\
120 & 1.56 & 1.42 & 1.22 & 1.40 & 1.30 & .10 \\
130 & 1.35 & 1.25 & 1.08 & 1.23 & 1.15 & .08 \\
135 & 1.24 & 1.16 & .99 & 1.13 & 1.00 & .13 \\
140 & 1.02 & .98 & .83 & .94 & .82 & .12 \\
150 & .55 & .45 & .34 & .45 & .34 & .11 \\
160 & -.14 & -.36 & -.39 & -.30 & -.32 & .02 \\
170 & .09 & -.07 & -.21 & -.06 & .08 & .02 \\
180 & 0 & .02 & .01 & .01 & .01 & 0 \\
\hline
\end{tabular}

TABLE 8.-The $y$ components of the force coefficients

\begin{tabular}{|c|c|c|c|c|c|c|}
\hline \multirow{2}{*}{$\begin{array}{l}\text { Angle of } \\
\text { wind } \\
\text { (degrees) }\end{array}$} & \multicolumn{4}{|c|}{ From pressure distribution data } & \multirow{2}{*}{$\begin{array}{c}\text { From } \\
\text { over- } \\
\text { turning } \\
\text { moments }\end{array}$} & \multirow{2}{*}{$\begin{array}{c}\text { Differ- } \\
\text { ence }\end{array}$} \\
\hline & $\begin{array}{c}\text { Elevation } \\
A\end{array}$ & $\underset{B}{\text { Elevation }}$ & $\underset{C}{\text { Elevation }}$ & Mean & & \\
\hline $\begin{array}{r}90 \\
100 \\
110 \\
120 \\
130 \\
135\end{array}$ & $\begin{array}{r}0.00 \\
-.21 \\
.29 \\
.84 \\
1.11 \\
1.26\end{array}$ & $\begin{array}{r}0.02 \\
-.28 \\
.07 \\
.67 \\
1.05 \\
1.20\end{array}$ & $\begin{array}{r}0.02 \\
-.35 \\
.04 \\
.57 \\
.93 \\
1.02\end{array}$ & $\begin{array}{r}0.02 \\
-.28 \\
.13 \\
.69 \\
1.03 \\
1.16\end{array}$ & $\begin{array}{r}-0.01 \\
-.20 \\
.21 \\
.65 \\
.91 \\
1.01\end{array}$ & $\begin{array}{l}0.03 \\
.08 \\
.08 \\
.04 \\
.12 \\
.15\end{array}$ \\
\hline $\begin{array}{l}140 \\
150 \\
160 \\
170 \\
180\end{array}$ & $\begin{array}{l}1.29 \\
1.44 \\
1.52 \\
1.57 \\
1.57\end{array}$ & $\begin{array}{l}1.27 \\
1.40 \\
1.47 \\
1.56 \\
1.57\end{array}$ & $\begin{array}{l}1.17 \\
1.31 \\
1.36 \\
1.42 \\
1.42\end{array}$ & $\begin{array}{l}1.24 \\
1.38 \\
1.45 \\
1.52 \\
1.52\end{array}$ & $\begin{array}{l}1.07 \\
1.16 \\
1.17 \\
1.27 \\
1.24\end{array}$ & $\begin{array}{l}.17 \\
.22 \\
.28 \\
.25 \\
.28\end{array}$ \\
\hline
\end{tabular}

\section{DISCUSSION}

In order to compare the pressure observations with the measurements of the overturning moment, the pressures were integrated by a process of numerical integration, namely, by multiplying the pressure at each hole by the distance between the midpoints of the distances to the two adjacent holes or to the edge of the face for the outer holes. The resulting sums for the $X$ and $Y$ components were divided by the width of the model in the $Y$ and $X$ directions and by the velocity pressure to give coefficients corresponding to those computed from the overturning moments. The coefficients for the three sections and the various angles are given in Tables 7 and 8, columns 2 and 4, inclusive, and the mean values are given in column 5 . Since there are no pressure stations on the tower which is of a different shape or on the lower part of the building which is in a region of reduced speed, the mean values in column 5 can not reasonably be expected to give a value representative of the entire building. Moreover, the coefficient from the overturning moment is truly representative only if the pressure is uniformly distributed. Nevertheless, the coefficients determined from the overturning moment are but 0.1 less than the mean value from the pressures measured at three levels for the $X$ direction and but 0.3 less for the $Y$ direction.

From a consideration of the values in the tables, we believe that for design purposes a coefficient of 1.5 is not unreasonable. 


\section{REMARKS ON THE METHOD OF COMPARING MODEL RESULTS WITH FULL-SCALE MEASUREMENTS}

Although this paper is concerned mainly with the model tests, it appears desirable to indicate the method of application of the results for comparisons with full-scale results and to explain one supplementary measurement made on the model. It has already been pointed out that in measurements in natural winds the wind speed and direction are not under control but vary continuously. Moreover it is certain that in a vertical distance of 1,250 feet there may be great variations of speed and direction at any instant. The only provision at present for measuring the wind speed on the actual building is an anemometer mounted about 15 feet above the top of the mooring tower. A little consideration shows that the indications of this instrument do not give the true speed of the wind approaching the building.

If the anemometer were placed on the windward side of the building on a median line not far from the wall of the building, it is easily seen that the readings would be too low, because the air is slowed up as it approaches the building. Moreover, if the anemometer were placed at the side of the building,

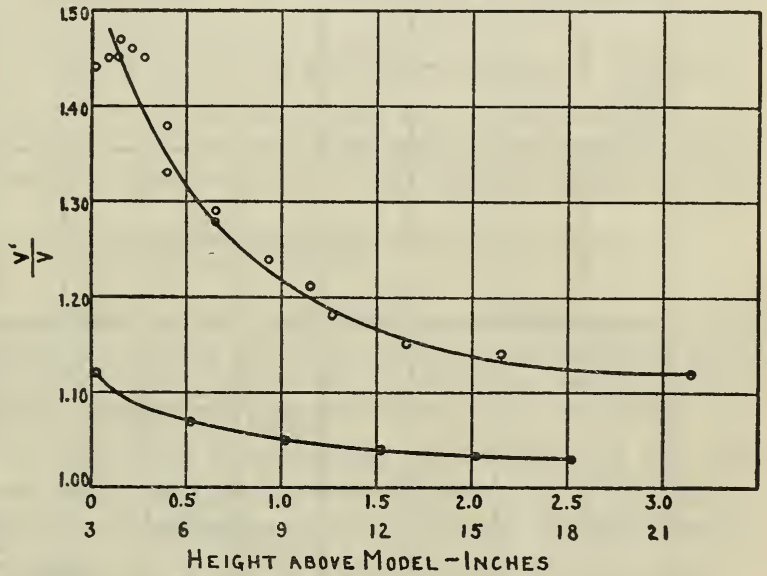

Frgure 20.-Distribution of wind speed above the model $V^{\prime}=$ local speed; $V=$ speed at the same place when the model is absent. The fact that the speed $V^{\prime}$ does not fall to $V$ is due to the blocking of the tunnel cross section by the model

it would read too high because the air blocked by the building must escape at higher speeds around the sides. A similar interference effect above the tower has been measured on the model. Figure 20 shows the variation of speed above the top of the tower. From this curve it is estimated that the anemometer on the building gives a speed about 23 per cent greater than the true speed of the approaching wind. When the anemometer reads 100 miles per hour (after correction for purely instrumental errors), the true speed of the approaching wind is 81 miles per hour. This correction must be applied to the readings of the anemometer on the building before comparison with the model tests.

In measurements in natural winds, it is practically impossible to secure a fixed reference pressure. In the case of the installation on the Empire State Building, it is not feasible to measure the pressures at the three levels with respect to the same base pressure. At each level, the base pressure is the pressure at some point within the building at the manometer location on that floor. The model results are expressed in terms of the static pressure and hence the $161541-33-7$ 
pressures at the individual stations are not directly comparable with those observed on the building.

Because of this fact and the previously noted variation of wind speed and direction at the different levels on the actual building, it is suggested that the comparison be made by assuming the model results to apply to the building and noting whether this assumption leads to inconsistencies. The procedure recommended is based on the fact that it is possible to choose stations such that certain ratios

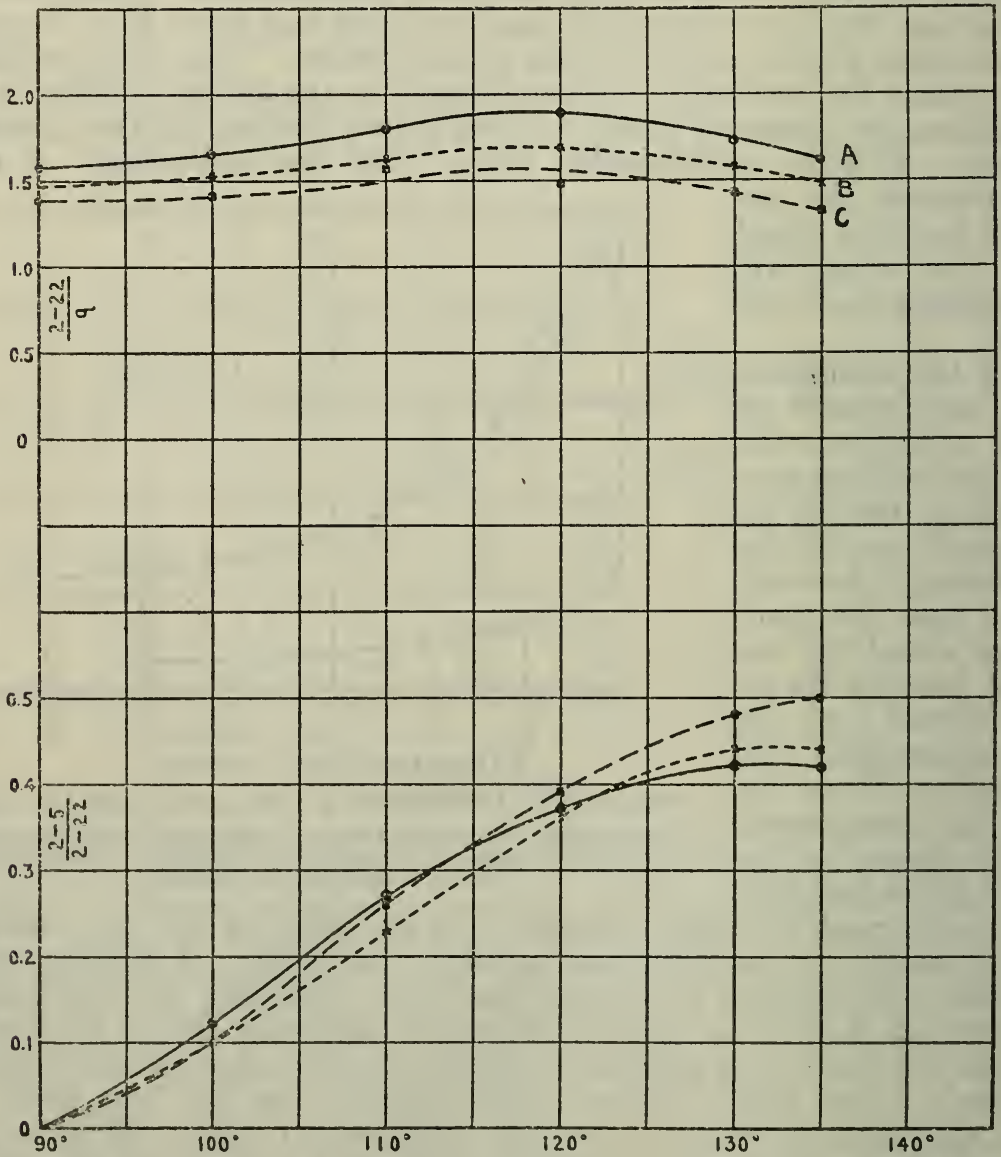

FIGURE 21.-Diagrams to show method of determining wind speed and direction at various levels on the full-scale building

The curves are from the model results. $2-5$ stands for the difference in pressure between stations 2 and 5 , etc.

of pressure differences are very sensitive to changes of wind direction whereas other ratios are insensitive.

The procedure is illustrated for wind directions lying between $90^{\circ}$ and $135^{\circ}$ in Figure 21. It is found that the ratio of the difference in pressure between stations 2 and 5 to that between stations 2 and 22 varies rapidly with wind direction. This ratio does not depend on the base pressure (if it is the same for the three stations) or on the 
wind speed (since all pressures vary in the same ratio with the speed). On the other hand, the ratio of the difference in pressure between stations 2 and 22 to the velocity pressure varies very slowly with the angle. Suppose that observations on the building at elevation B give a value of 0.36 for the ratio $\frac{2-5}{2-22}$. From the lower curve of Figure 21 , the wind direction is found to be $120^{\circ}$ and from the upper curve $\frac{2-22}{q}$ is found to be 1.7 . From the value of $2-22, q$ may be found and thence from Table 2 the speed. The value of the speed and direction can be compared with that obtained for the other two levels and the top of the building. Likewise, since the maximum increase in pressure should be equal to $q$, the difference between the base pressure and the static pressure can be evaluated, the diagrams reduced to the same base pressure, and the shape of the distribution curves compared. If no inconsistencies appear, it may be concluded that the full-scale and model tests are not inconsistent, No better procedure appears possible without an elaborate installation of anemometers at different levels on the building and an expensive interconnection of the reference pressure sides of the manometers by pipes of large diameter.

\section{CONCLUSION}

To summarize, a reasonable value of the force coefficient for use in the design of tall buildings appears to be 1.5 corresponding to a wind pressure equal to $0.0038 V^{2}$ (in lbs./ft. ${ }^{2}$ ) where $V$ is the true speed of the approaching wind in miles per hour.

Data are given for the detailed distribution of pressure at 102 stations for wind directions varying by steps of $10^{\circ}$.

A suggested method of comparison with full-scale measurements is outlined.

Washington, February 13, 1933. 